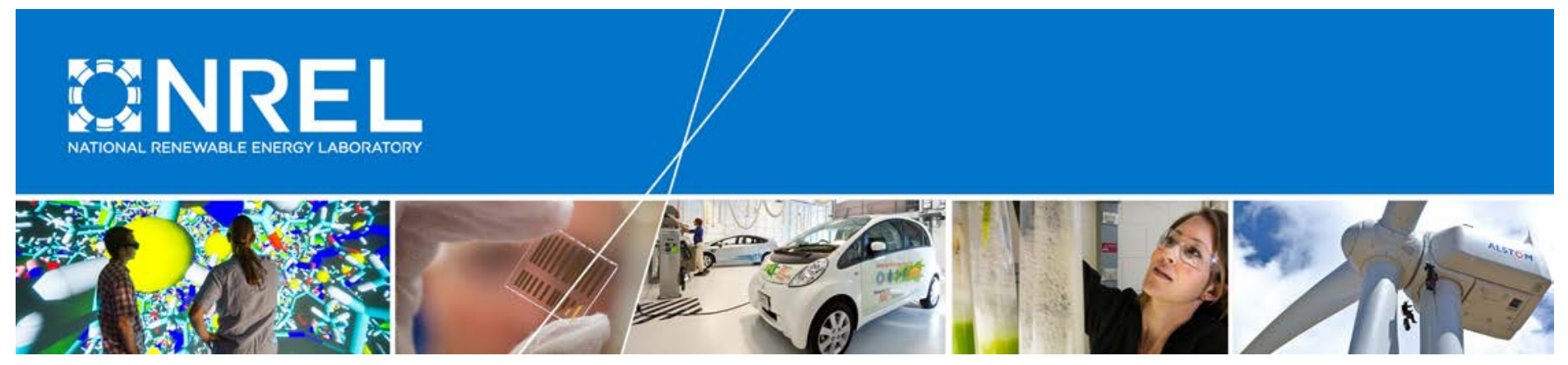

\title{
Power Performance Test Report for the U.S. Department of Energy 1.5-Megawatt Wind Turbine
}

Ismael Mendoza, Jerry Hur, and Syhoune Thao National Renewable Energy Laboratory

Amy Curtis

Windward Engineering

NREL is a national laboratory of the U.S. Department of Energy Office of Energy Efficiency \& Renewable Energy Operated by the Alliance for Sustainable Energy, LLC

This report is available at no cost from the National Renewable Energy Laboratory (NREL) at www.nrel.gov/publications.

Technical Report

NREL/TP-5000-63684

August 2015

Contract No. DE-AC36-08GO28308 


\section{Power Performance Test Report for the U.S. Department of Energy 1.5-Megawatt Wind Turbine}

Ismael Mendoza, Jerry Hur, and Syhoune Thao National Renewable Energy Laboratory

Amy Curtis

Windward Engineering

Prepared under Task No. WE15.1A02
NREL is a national laboratory of the U.S. Department of Energy Office of Energy Efficiency \& Renewable Energy Operated by the Alliance for Sustainable Energy, LLC

This report is available at no cost from the National Renewable Energy Laboratory (NREL) at www.nrel.gov/publications.

\section{Technical Report}

NREL/TP-5000-63684

August 2015

Contract No. DE-AC36-08G028308
National Renewable Energy Laboratory 15013 Denver West Parkway Golden, CO 80401 303-275-3000 • www.nrel.gov 


\title{
NOTICE
}

This report was prepared as an account of work sponsored by an agency of the United States government. Neither the United States government nor any agency thereof, nor any of their employees, makes any warranty, express or implied, or assumes any legal liability or responsibility for the accuracy, completeness, or usefulness of any information, apparatus, product, or process disclosed, or represents that its use would not infringe privately owned rights. Reference herein to any specific commercial product, process, or service by trade name, trademark, manufacturer, or otherwise does not necessarily constitute or imply its endorsement, recommendation, or favoring by the United States government or any agency thereof. The views and opinions of authors expressed herein do not necessarily state or reflect those of the United States government or any agency thereof.

This report is available at no cost from the National Renewable Energy Laboratory (NREL) at www.nrel.gov/publications.

Available electronically at SciTech Connect http:/www.osti.gov/scitech

Available for a processing fee to U.S. Department of Energy and its contractors, in paper, from:

\author{
U.S. Department of Energy \\ Office of Scientific and Technical Information \\ P.O. Box 62 \\ Oak Ridge, TN 37831-0062 \\ OSTI http://www.osti.gov \\ Phone: 865.576.8401 \\ Fax: 865.576.5728 \\ Email: reports@osti.gov
}

Available for sale to the public, in paper, from:

\author{
U.S. Department of Commerce \\ National Technical Information Service \\ 5301 Shawnee Road \\ Alexandria, VA 22312 \\ NTIS http://www.ntis.gov \\ Phone: 800.553 .6847 or 703.605 .6000 \\ Fax: 703.605.6900 \\ Email: orders@ntis.gov
}




\title{
Power Performance Test Report
}

for the

\section{DOE 1.5-MW Wind Turbine}

\author{
in \\ Golden, Colorado, USA \\ Conducted for
}

U.S. Department of Energy Office of Energy Efficiency and Renewable Energy

Wind and Water Power Program

Forrestal Building

1000 Independence Avenue, SW

Washington, DC 20585

Conducted by

National Wind Technology Center

National Renewable Energy Laboratory

15013 Denver West Parkway

Golden, Colorado 80401

Ismael Mendoza, Amy Curtis, Jerry Hur, and Simon Thao

October 2014 


\section{Notice}

This report was prepared by the National Renewable Energy Laboratory (NREL), operated for the United States Department of Energy (DOE) by the Alliance for Sustainable Energy, LLC (Alliance), as an account of work sponsored by the United States government. The test results documented in this report define the characteristics of the test article as configured and under the conditions tested.

THIS REPORT IS PROVIDED "AS IS" AND NEITHER THE GOVERNMENT, ALLIANCE, NREL NOR ANY OF THEIR EMPLOYEES, MAKES ANY WARRANTY, EXPRESS OR IMPLIED, INCLUDING THE WARRANTIES OF MERCHANTABILITY AND FITNESS FOR A PARTICULAR PURPOSE, OR ASSUMES ANY LEGAL LIABILITY OR RESPONSIBILITY FOR THE ACCURACY, COMPLETENESS, OR USEFULNESS OF ANY SUCH INFORMATION DISCLOSED IN THE REPORT, OR OF ANY APPARATUS, PRODUCT, OR PROCESS DISCLOSED, OR REPRESENTS THAT ITS USE WOULD NOT INFRINGE PRIVATELY OWNED RIGHTS.

Neither Alliance nor the U. S. Government shall be liable for special, consequential or incidental damages. Reference herein to any specific commercial product, process, or service by trade name, trademark, manufacturer, or otherwise does not necessarily constitute or imply its endorsement, recommendation, or favoring by the United States government or any agency thereof. The views and opinions of the authors expressed herein do not necessarily state or reflect those of the United States government or any agency thereof or Alliance.

NREL is a DOE Laboratory, and as an adjunct of the United States government, cannot certify wind turbines. The information in this report is limited to NREL's knowledge and understanding as of this date.

NREL is accredited by the American Association for Laboratory Accreditation (A2LA) and the results shown in this test report have been determined in accordance with the NREL's terms of accreditation unless stated otherwise in the report.

This report shall not be reproduced, except in full, without the written approval of Alliance or successor operator of NREL.

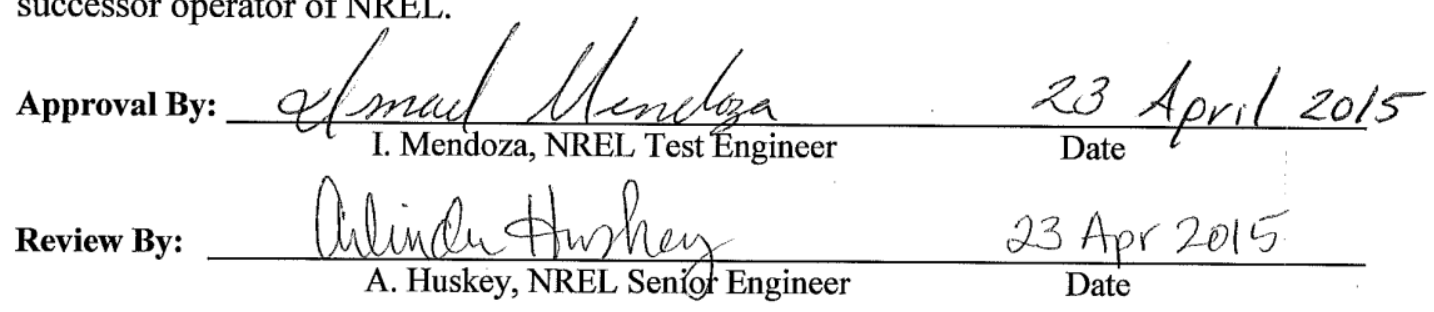




\section{Table of Contents}

1 Background

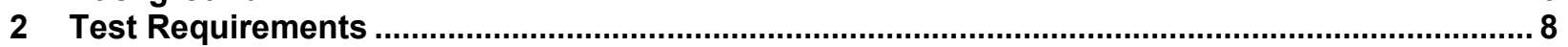

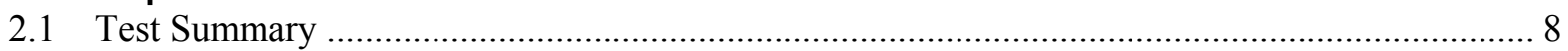

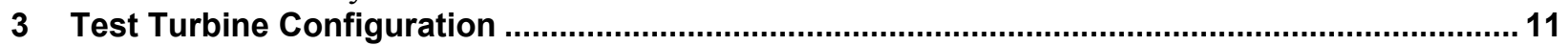

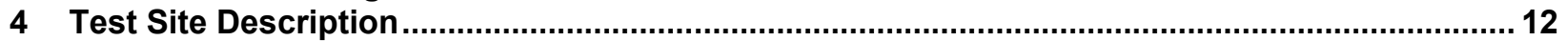

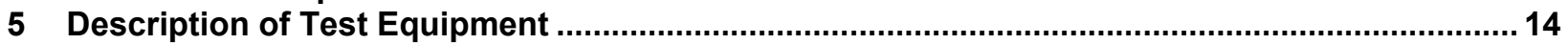

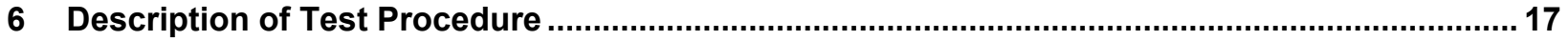

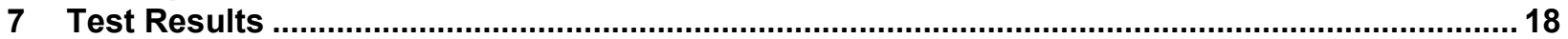

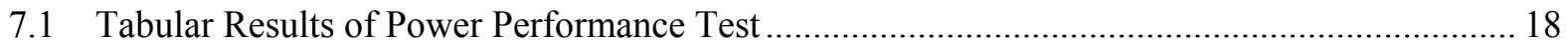

7.2 Graphical Results Power Performance Test ....................................................................... 21

8 Exceptions

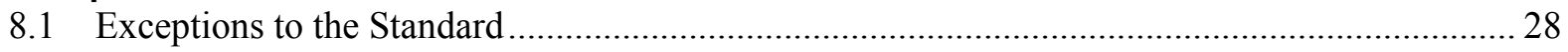

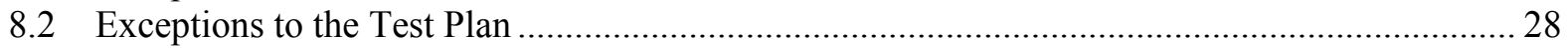

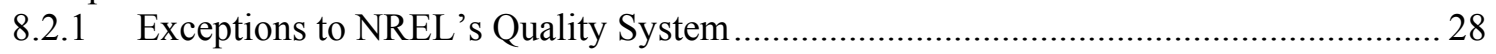

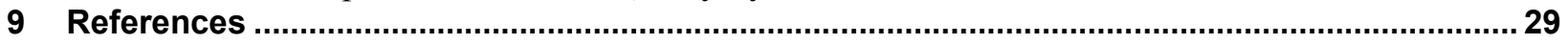

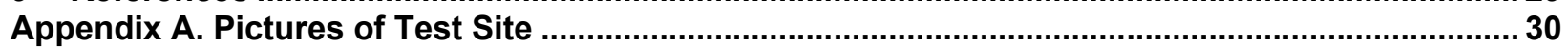

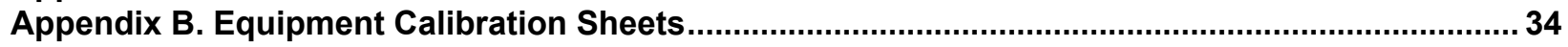

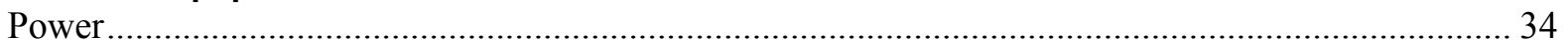

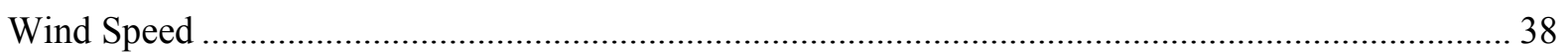

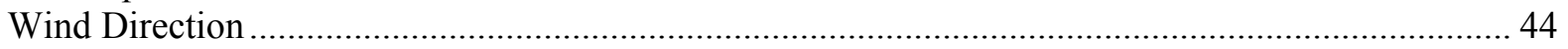

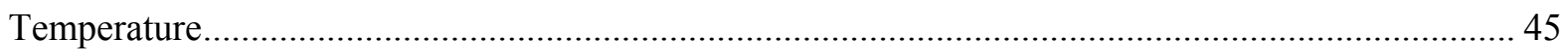

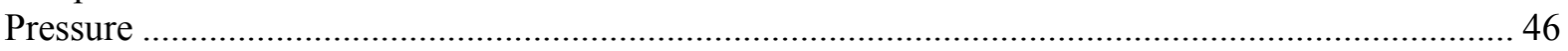

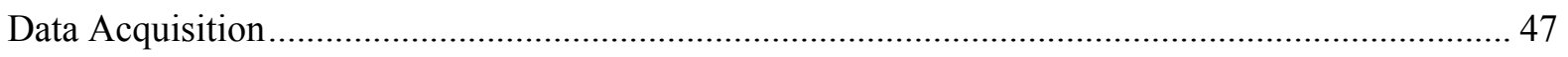




\section{List of Figures}

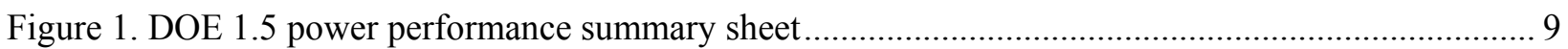

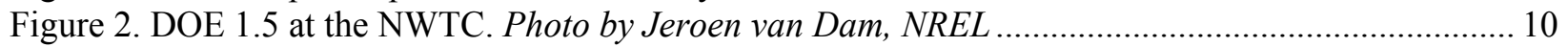

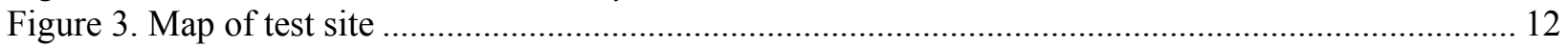

Figure 4. Meteorological (met) tower with instrument configuration. Illustration by Ismael Mendoza,

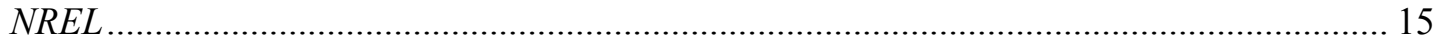

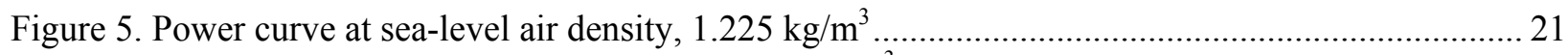

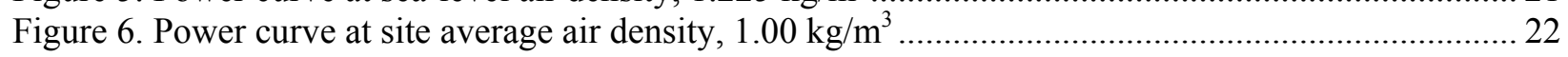

Figure 7. Scatterplot averages, standard deviation, minimum, maximum power as a function of wind speed normalized to site average air density, $1.00 \mathrm{~kg} / \mathrm{m}^{3}$....

Figure 8. Coefficient of performance at sea-level air density, $1.225 \mathrm{~kg} / \mathrm{m}^{3}$, with turbine rotor swept area $=$

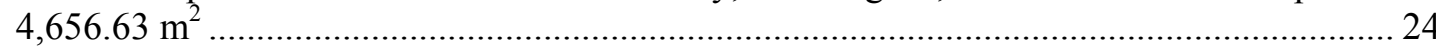

Figure 9. Coefficient of performance at site average air density, $1.00 \mathrm{~kg} / \mathrm{m}^{3}$, with turbine rotor swept area

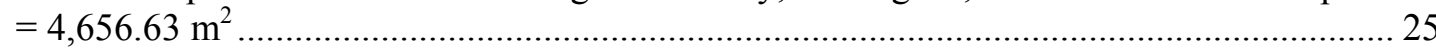

Figure 10. Wind speed and turbulence intensity as a function of wind direction................................. 26

Figure 11. Wind turbulence as a function of wind speed..................................................................... 27

Figure A-1. At the base of the tower facing north. Photo by Ismael Mendoza, NREL ............................. 30

Figure A-2. At the base of the tower facing northeast. Photo by Ismael Mendoza, NREL ........................ 30

Figure A-3. At the base of the tower facing east. Photo by Ismael Mendoza, NREL ............................. 31

Figure A-4. At the base of the tower facing southeast. Photo by Ismael Mendoza, NREL....................... 31

Figure A-5. At the base of the tower facing south. Photo by Ismael Mendoza, NREL ............................. 32

Figure A-6. At the base of the tower facing southwest. Photo by Ismael Mendoza, NREL ........................ 32

Figure A-7. At the base of the tower facing west. Photo by Ismael Mendoza, NREL .............................. 33

Figure A-8. At the base of the tower facing northwest. Photo by Ismael Mendoza, NREL ........................ 33

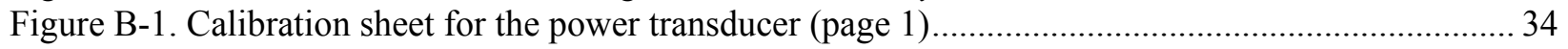

Figure B-2. Calibration sheet for the power transducer (page 2) ..................................................... 35

Figure B-3. Calibration sheet for the power transducer (page 3) ......................................................... 36

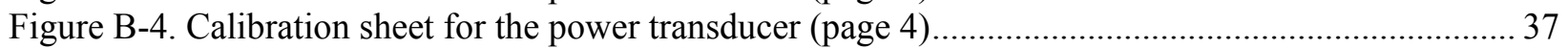

Figure B-5. Calibration sheet for the primary anemometer (page 1) ................................................. 38

Figure B-6. Calibration sheet for the primary anemometer (page 2) ............................................... 39

Figure B-7. Calibration sheet for the primary anemometer (page 3) ................................................. 40

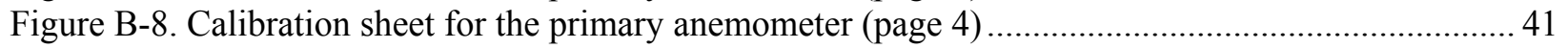

Figure B-9. Calibration sheet for the primary anemometer (page 5) ............................................... 42

Figure B-10. Calibration sheet for the reference anemometer (page 1) ............................................... 43

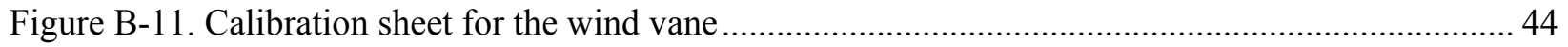

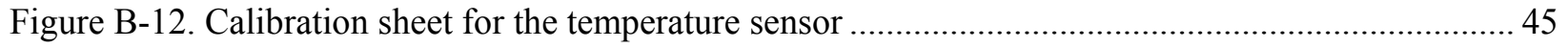

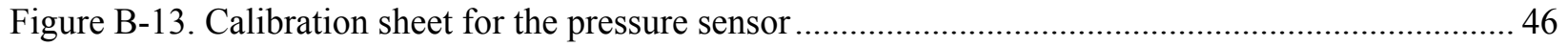

Figure B-14. Certificate of conformance sheet for NI 9229 signal module ............................................ 47

Figure B-15. Calibration sheet for NI 9229 signal module 12B6DD2 …............................................. 48

Figure B-16. Certificate of conformance sheet for NI 9217 signal module 12BD192 .......................... 49

Figure B-17. Calibration sheet for NI 9217 signal module 12BD192 …............................................... 50

Figure B-18. Certificate of conformance sheet for NI 9205 signal module 12E9CD3 …........................ 51

Figure B-19. Calibration sheet for NI 9205 signal module 12E9CD3 ................................................. 52 


\section{List of Tables}

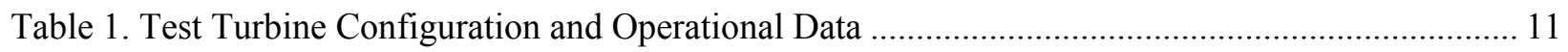

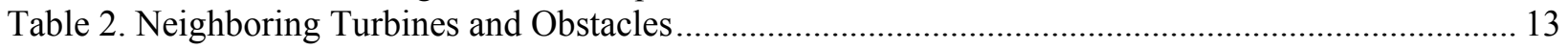

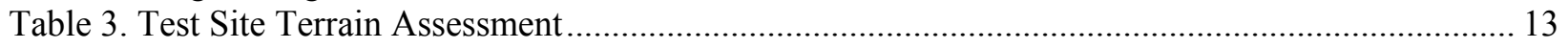

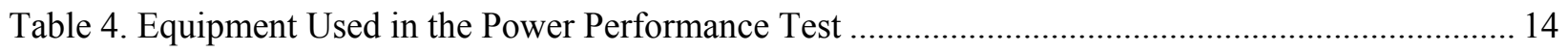

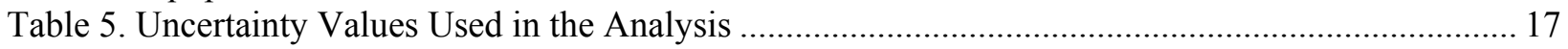

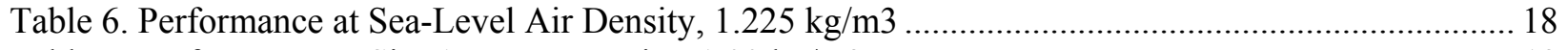

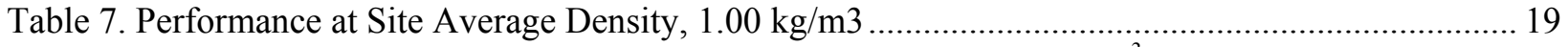

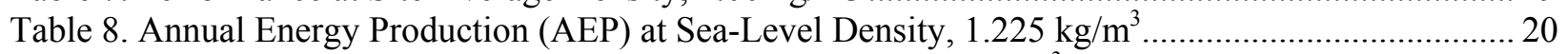

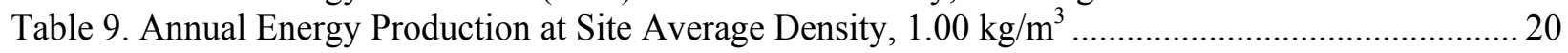




\section{Background}

The U.S. Department of Energy (DOE) acquired and installed a 1.5-megawatt (MW) wind turbine at the National Wind Technology Center (NWTC) at the National Renewable Energy Laboratory (NREL). This turbine (hereafter referred to as the DOE 1.5) is envisioned to become an integral part of the research initiatives for the DOE Wind Program, such as Atmosphere to Electrons (A2e). A2e is a multiyear DOE research initiative targeting significant reductions in the cost of wind energy through an improved understanding of the complex physics governing wind flow into and through wind farms. For more information, visit http://energy.gov/eere/wind/atmosphere-electrons.

To validate new and existing high-fidelity simulations, A2e must deploy several experimental measurement campaigns across different scales. Proposed experiments include wind tunnel tests, scaled field tests, and large field measurement campaigns at operating wind plants. Data of interest includes long-term atmospheric data sets, wind plant inflow, intra-wind plant flows (e.g., wakes), and rotor loads measurements. It is expected that new, high-fidelity instrumentation will be required to successfully collect data at the resolutions required to validate the high-fidelity simulations.

The large-scale field measurement campaigns are expected to use the DOE 1.5 as it is of sufficient enough size to represent current technology, and turbines of this size are widely deployed in U.S. wind plants.

Expected future use of the DOE 1.5 at the NWTC may include the following (leading up to the large files measurement campaigns at operating plants):

- Deployment and validation of high-fidelity instrumentation prior to large-scale deployment at a wind plant

- Deployment of advanced controls algorithms

- Characterization of inflow, aerodynamics, turbine loads, and wake propagation on an unwaked turbine.

A series of tests were conducted to characterize the baseline properties and performance of the DOE 1.5 to enable research model development and quantify the effects of future turbine research modifications.

The tests included:

- Power performance per International Electrotechnical Commission (IEC) 61400-12-1

- $\quad$ Power quality per IEC 61400-21

- Acoustic noise per IEC 61400-11

- Mechanical loads per IEC 61400-13

- Modal testing. 
The DOE 1.5 is built on the platform of GE's 1.5-MW SLE commercial wind turbine model. It was installed in a nonstandard configuration at the NWTC with the objective of supporting DOE Wind Program research initiatives such as A2e. Therefore, the test results may not represent the performance capabilities of other GE 1.5-MW SLE turbines.

The power performance test documented in this report is one of a series of tests carried out to establish a performance baseline for the DOE 1.5 in the NWTC inflow environment. 


\section{Test Requirements}

NREL conducted this test in accordance with the International Electrotechnical Commission's (IEC) standard, Wind Turbine Generator Systems - Part 12-1: Wind turbines - Power performance measurements of electricity producing wind turbines, IEC 61400-12-1, Edition 1.0, 2005-12 [1] — hereafter referred to as the Standard.

Additionally, NREL conducted this test in accordance with its quality system procedures such that the final test report meets the full requirements of its accreditation by A2LA. NREL's quality system requires that all applicable requirements specified by A2LA and ISO/IEC 17025 are met and any exceptions in the test noted in the test report.

\subsection{Test Summary}

The DOE 1.5 power performance test began on February 28, 2011, and ended on June 21, 2011. During that period, 262 hours of valid data were collected. The Standard requires at least three 10 -minute wind speed averaged data points ranging from $1 \mathrm{~m} / \mathrm{s}$ below cut-in up to $16 \mathrm{~m} / \mathrm{s}$ in 0.5 $\mathrm{m} / \mathrm{s}$ increments. When the data was binned by wind speed, more than three data points were recorded for each bin. According to the Standard, sufficient data was collected. The highest bin filled (with no wind speed normalization) was the $21.5 \mathrm{~m} / \mathrm{s}$ bin.

Figure 1 is a summary of the results of the power performance test that NREL conducted on the DOE 1.5. These results are normalized to sea-level air density. Further details of these results are given in the Results section. Figure 2 shows a picture of the DOE 1.5 installed at the NWTC site. 


\begin{tabular}{|c|c|c|c|c|}
\hline & $\begin{array}{c}\text { Bin Wind } \\
\text { Speed } \\
(\mathrm{m} / \mathrm{s})\end{array}$ & $\begin{array}{c}\text { Bin } \\
\text { Power } \\
\text { (kW) } \\
\end{array}$ & $\begin{array}{c}\text { Number } \\
\text { Data } \\
\text { Points }\end{array}$ & $C p$ \\
\hline & 1.01 & -4.92 & 11 & -1.65 \\
\hline & 1.53 & -5.44 & 25 & -0.53 \\
\hline & 1.99 & -5.78 & 34 & -0.26 \\
\hline & 2.43 & -5.56 & 34 & -0.14 \\
\hline & 2.97 & 0.59 & 15 & 0.01 \\
\hline & 3.51 & 18.91 & 31 & 0.15 \\
\hline & 3.97 & 58.88 & 42 & 0.33 \\
\hline & 4.52 & 100.82 & 42 & 0.38 \\
\hline & 5.01 & 162.89 & 47 & 0.45 \\
\hline & 5.52 & 235.10 & 57 & 0.49 \\
\hline & 5.99 & 303.63 & 81 & 0.49 \\
\hline & 6.52 & 399.01 & 74 & 0.51 \\
\hline & 7.04 & 513.90 & 64 & 0.52 \\
\hline & 7.51 & 608.80 & 75 & 0.50 \\
\hline & 8.00 & 742.33 & 78 & 0.51 \\
\hline & 8.49 & 853.63 & 73 & 0.49 \\
\hline & 9.01 & 975.43 & 80 & 0.47 \\
\hline & 9.52 & $1,096.64$ & 74 & 0.44 \\
\hline$s^{2}+2$ & 10.03 & $1,200.18$ & 62 & 0.42 \\
\hline $\mathrm{m}$ & 10.48 & $1,259.60$ & 50 & 0.38 \\
\hline & 10.99 & $1,317.72$ & 61 & 0.35 \\
\hline & 11.49 & $1,389.96$ & 71 & 0.32 \\
\hline & 11.98 & $1,400.22$ & 41 & 0.29 \\
\hline & 12.52 & $1,453.27$ & 59 & 0.26 \\
\hline & 12.97 & $1,452.29$ & 41 & 0.23 \\
\hline & 13.51 & $1,477.63$ & 36 & 0.21 \\
\hline & 13.97 & $1,481.77$ & 35 & 0.19 \\
\hline & 14.43 & $1,495.62$ & 22 & 0.17 \\
\hline & 15.01 & $1,497.75$ & 23 & 0.16 \\
\hline ees true & 15.49 & $1,494.80$ & 14 & 0.14 \\
\hline & 15.98 & $1,496.56$ & 13 & 0.13 \\
\hline & 16.46 & $1,505.16$ & 13 & 0.12 \\
\hline & 16.97 & $1,505.79$ & 20 & 0.11 \\
\hline & 17.52 & $1,511.65$ & 18 & 0.10 \\
\hline & 18.00 & $1,497.01$ & 16 & 0.09 \\
\hline & 18.47 & $1,509.12$ & 13 & 0.08 \\
\hline & 19.06 & $1,499.37$ & 8 & 0.08 \\
\hline & 19.40 & $1,501.96$ & 4 & 0.07 \\
\hline & 19.96 & $1,511.18$ & 3 & 0.07 \\
\hline & 20.51 & $1,507.56$ & 7 & 0.06 \\
\hline & 20.95 & $1,502.55$ & 3 & 0.06 \\
\hline & 21.45 & $1,499.10$ & 4 & 0.05 \\
\hline
\end{tabular}

Power Performance Test

DOE/GE 1.5SLE

Sea-Level Density Power Curve

Turbine Specifications:

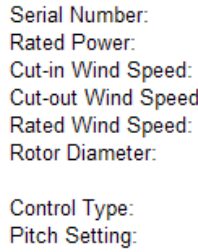

Site Conditions:

Location:

Average Air Density: Measurement Sectors:

Test Statistics:

$\begin{array}{lc}\text { Start Date: } & \text { 28-Feb-2011 } \\ \text { End Date: } & \text { 21-Jun-2011 } \\ \text { Amount of Data Collected: } & 262.33 \text { hours } \\ \text { Highest Bin Filled: } & 21.50 \mathrm{~m} / \mathrm{s} \\ \text { Test Completed? } & \text { Yes }\end{array}$

NWTC, Boulder, CO

$$
0.99 \mathrm{~kg} / \mathrm{m}^{3}
$$

243-310 degrees true

Yes

Sea-Level Air Density Normalized Power Curve

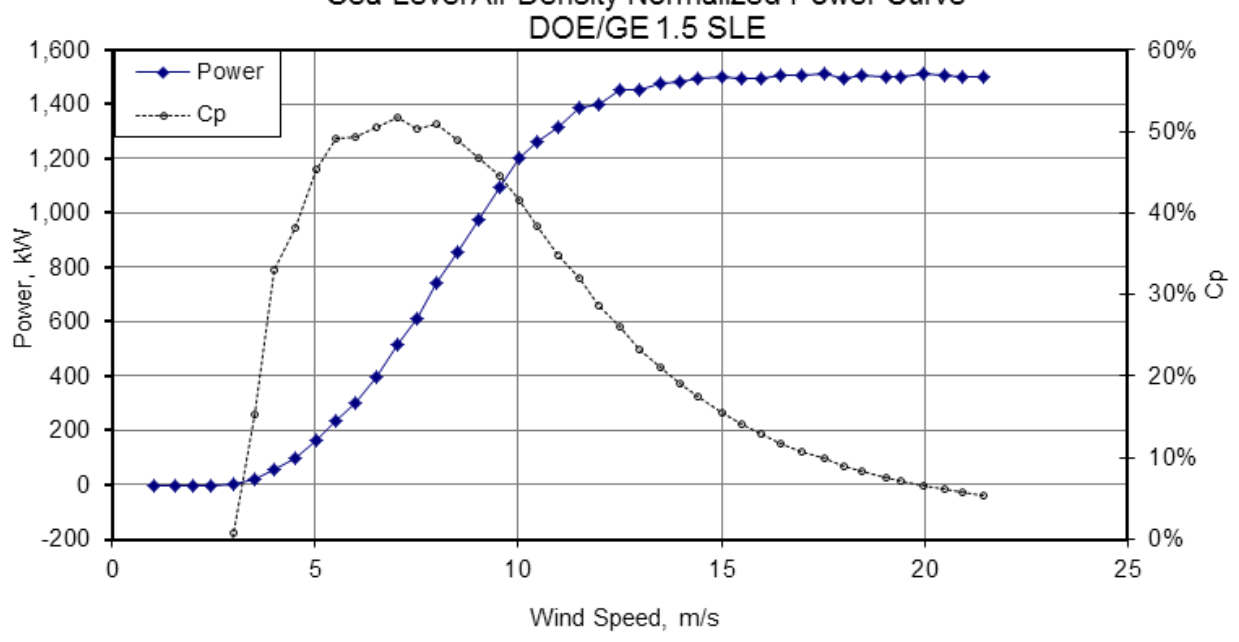

Figure 1. DOE 1.5 power performance summary sheet 


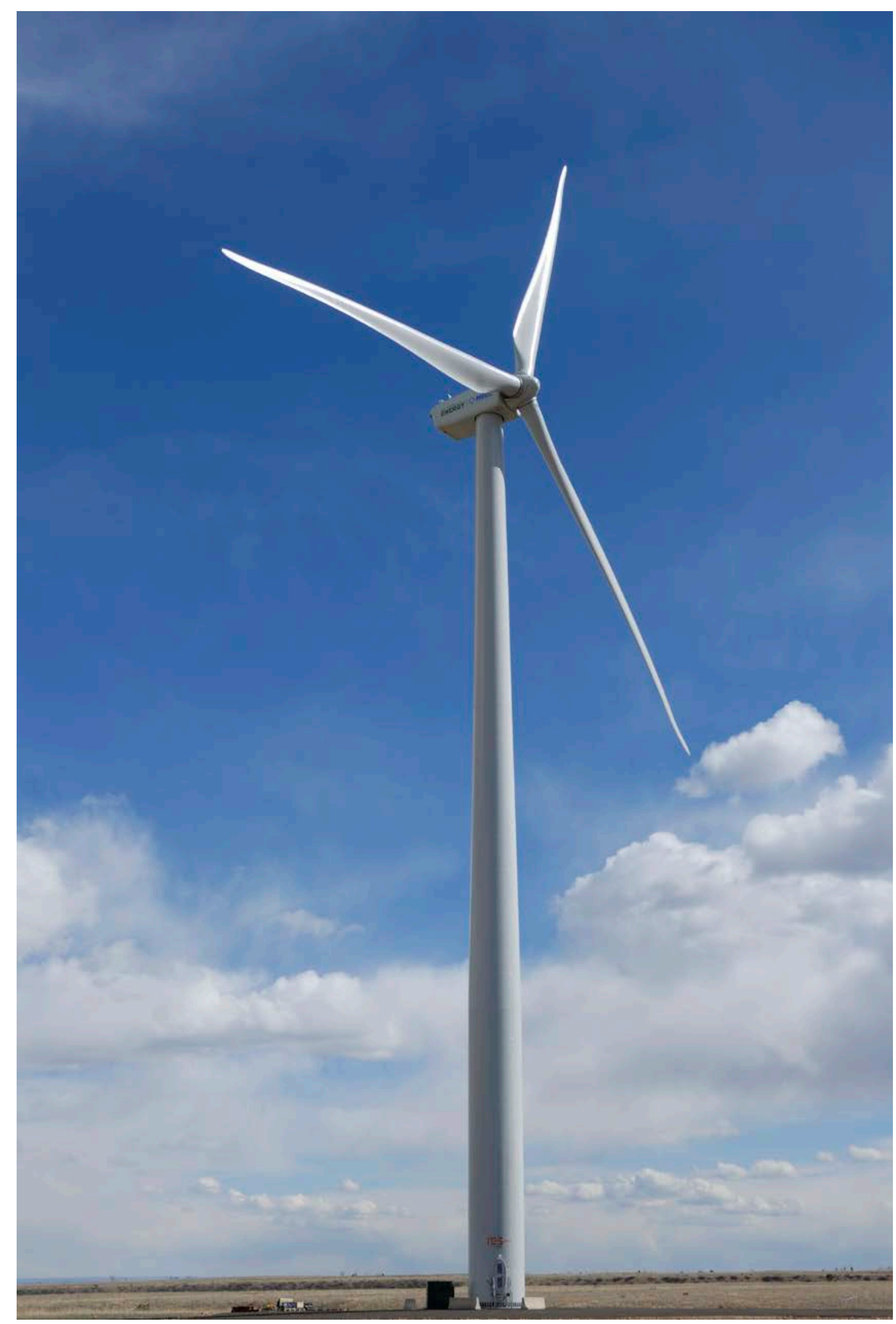

Figure 2. DOE 1.5 at the NWTC. Photo by Jeroen van Dam, NREL 


\section{Test Turbine Configuration}

The turbine under test was a horizontal-axis, three-bladed, upwind machine with pitch control. Table 1 provides the key descriptive information of the test turbine.

Table 1. Test Turbine Configuration and Operational Data

\begin{tabular}{|l|r|}
\hline Turbine manufacturer and address & $\begin{array}{r}\text { GE Energy } \\
\text { Model }\end{array}$ \\
\hline Serial number & $\begin{array}{r}\text { Garlington Rd., P.O. Box 648 } \\
\text { Greenville, SC 29602-0648 }\end{array}$ \\
\hline Rotor diameter $(\mathrm{m})$ & GE 1.5 SLE \\
\hline Hub height $(\mathrm{m})$ & TB059-3 \\
\hline Tower type & 77 \\
\hline Rated electrical power $(\mathrm{kW})$ & Tubular \\
\hline Rated wind speed $(\mathrm{m} / \mathrm{s})$ & 1,500 \\
\hline Cut-out wind speed $(\mathrm{m} / \mathrm{s})(600$ s average) & 14 \\
\hline Rotor speed range $(\mathrm{rpm})$ & 25 \\
\hline Fixed or variable pitch & $10-20$ \\
\hline Number of blades & Variable \\
\hline Blade pitch angle $($ deg) & 3 \\
\hline Blade make, type, serial number & Variable \\
\hline Description of control system (device and software version) & GE37c, S00028,S00029,S00030 \\
\hline Type class & ESS \\
\hline
\end{tabular}




\section{Test Site Description}

The turbine was located at test site 4.0 of the NWTC, approximately 8 miles south of Boulder, Colorado. The terrain consists of mostly flat land with short vegetation (see Appendix A for photos of the test site). The site has prevailing winds bearing 292 degrees relative to true north. Figure 3 shows the turbine and meteorological (met) tower locations. This figure also shows nearby obstructions and topographical features of the site. To minimize the influence of obstructions and terrain during this test, NREL established a measurement sector from $243^{\circ}$ to $310^{\circ}$. This measurement sector was derived according to the Standard's obstacles assessment criteria in Annex A. The obstructions are listed in Table 2 and are identified on the map in Figure 3. NREL limited it's assessments of power and energy production to data obtained when winds were within the measurement sector.

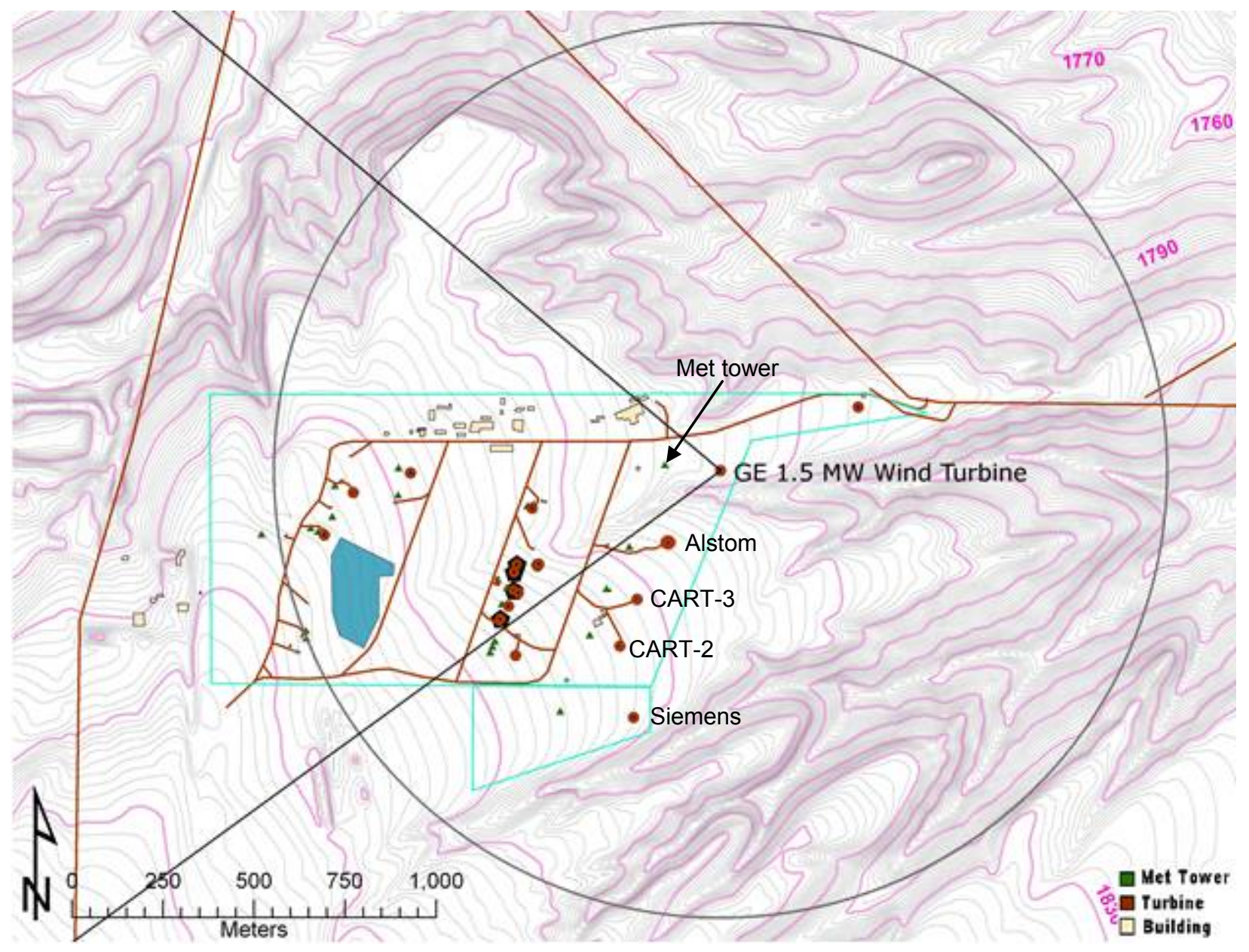

Figure 3. Map of test site 
Table 2. Neighboring Turbines and Obstacles

\begin{tabular}{|c|c|c|c|c|c|c|}
\hline \multirow{2}{*}{$\begin{array}{l}\text { Obstacle } \\
\text { or Turbine }\end{array}$} & \multirow{2}{*}{$\begin{array}{c}\text { Relative } \\
\text { to: }\end{array}$} & \multirow{2}{*}{$\begin{array}{c}\text { Distance } \\
\text { (m) }\end{array}$} & \multirow{2}{*}{$\begin{array}{l}\text { Bearing } \\
(\operatorname{deg} \mathrm{T})\end{array}$} & \multirow{2}{*}{$\begin{array}{l}\text { Equiv. } \\
\text { Dia. } \\
(\mathrm{m})\end{array}$} & \multicolumn{2}{|c|}{ Obstructed Sector } \\
\hline & & & & & $\begin{array}{c}\text { Start } \\
(\operatorname{deg} T)\end{array}$ & $\begin{array}{c}\text { End } \\
(\operatorname{deg} T)\end{array}$ \\
\hline Alstom & Test Turbine & 219 & 204 & 101 & 124 & 242 \\
\hline CART-2 & Test Turbine & 557 & 211 & 40 & 172 & 233 \\
\hline CART-3 & Test Turbine & 422 & 214 & 43 & 177 & 227 \\
\hline Siemens & Test Turbine & 718 & 200 & 101 & 165 & 222 \\
\hline Test Turbine & Met Tower & 153.43 & 100 & $\mathrm{~N} / \mathrm{A}$ & 46 & 146 \\
\hline
\end{tabular}

NREL completed the site assessment requirements of Annex B of the Standard. Table 3 shows the results from the site assessment, which indicates that a site calibration is required because of the terrain variation; however, the client and NREL agreed not to perform a site calibration and instead increased the uncertainty in the analysis for flow distortion as a result of the terrain. This was noted as a deviation of the Standard.

Table 3. Test Site Terrain Assessment

DOE 1.5

Site: 4.0

Measurement Sector: $\quad 243$ to $\quad 310$ deg True

Criteria for Test Site without Site Calibration Testing

\begin{tabular}{|c|c|c|c|c|c|c|}
\hline Criterion & Description & Distance & $\begin{array}{l}\text { Sector } \\
\text { (deg) }\end{array}$ & allowable & $\begin{array}{l}\text { Test Site } \\
\text { Condition }\end{array}$ & Pass/Fail \\
\hline 1 & Maximum slope of best fit plane $<3 \%$ & $<2 L$ & 360 & $3 \%$ & $2.4 \%$ & Pass \\
\hline 2 & Maximum variation from best fit plane $<0.04(\mathrm{H}+\mathrm{D}$ & $<2 \mathrm{~L}$ & 360 & $+/-5.9 m$ & 15.7 & Fail \\
\hline 3 & Maximum slope of best fit plane $<5 \%$ & $2-4 \mathrm{~L}$ & $\ln$ & $5 \%$ & $1.5 \%$ & Pass \\
\hline 4 & Maximum variation from best fit plane $<0.08(\mathrm{H}+\mathrm{D}$ & $2-4 \mathrm{~L}$ & $\ln$ & $+-11.8 m$ & 2.6 & Pass \\
\hline 5 & Steepest slope maximum $<10 \%$ & $2-4 L$ & Out & $10 \%$ & $1.7 \%$ & Pass \\
\hline 6 & Maximum slope of best fit plane $<10 \%$ & $4-8 \mathrm{~L}$ & $\ln$ & $10 \%$ & $2.1 \%$ & Pass \\
\hline 7 & Maximum variation from best fit plane $<0.13(\mathrm{H}+\mathrm{D}$ & $4-8 \mathrm{~L}$ & $\ln$ & $+/-19.2 m$ & 19.2 & Pass \\
\hline 8 & No neighboring and operating turbines & $<2 D_{n}$ & 360 & 0 & 0 & Pass \\
\hline 9 & No obstacles & $<2 \mathrm{D}_{\mathrm{e}}$ & 360 & 0 & 0 & Pass \\
\hline
\end{tabular}

Site Calibration Required?

yes

absolute value used for site condition In = Inside Preliminary Measurement Sector Out $=$ Outside Preliminary Measurement Sector 


\section{Description of Test Equipment}

Table 4 shows the equipment used and calibration due dates. Appendix B of this report contains the calibration sheets. Figure 4 depicts the placement of the meteorological instruments on the tower. An additional exception to the Standard was taken because of the deviation of the recommended anemometer mounting. Additional uncertainty was included in the analysis regarding the mounting effects. At the end of the test, an in situ comparison was performed on the primary anemometer with the reference anemometer as prescribed in the Standard to verify that the primary anemometer did not change its calibration during the measurement period. The results showed a difference of less than $0.1 \mathrm{~m} / \mathrm{s}$ for the range of $6-12 \mathrm{~m} / \mathrm{s}$ and within the tolerances allowed by the Standard.

Table 4. Equipment Used in the Power Performance Test

\begin{tabular}{|c|c|c|c|}
\hline Instrument & Make, Model & Serial Number & Calibration Due Date \\
\hline Power transducer & Ohio Semitronics DWV-008D & 09070337 & January 7, 2012 \\
\hline Primary anemometer & Thies, First Class & 0909219 & December 20, 2011 \\
\hline $\begin{array}{l}\text { Reference } \\
\text { anemometer }\end{array}$ & Met One, SS-201 & K16684 & in situ \\
\hline Wind vane & $\begin{array}{l}\text { Met One, SD-201 with } \\
\text { aluminum vane }\end{array}$ & K16689 & January 5, 2012 \\
\hline Pressure sensor & Vaisala, PTB101B & B2130018 & December 22, 2011 \\
\hline Temperature sensor & Met One, T-200 & 0673552 & December 22, 2011 \\
\hline Precipitation sensor & Campbell Scientific, 237 & None & in situ \\
\hline $\begin{array}{l}\text { Data acquisition } \\
\text { system }\end{array}$ & $\begin{array}{l}\text { Compact DAQ w/LabView-based } \\
\text { data acquisition } \\
\text { cDAQ-9172 } \\
\text { NI } 9229 \\
\text { NI } 9217 \\
\text { NI } 9205\end{array}$ & $\begin{array}{c}1361570 \\
\text { 12B6DD2 } \\
\text { 12BD192 } \\
\text { 12E9CD3 }\end{array}$ & $\begin{array}{l}\text { August 21, } 2011 \\
\text { August 21, } 2011 \\
\text { August 21, } 2011\end{array}$ \\
\hline
\end{tabular}




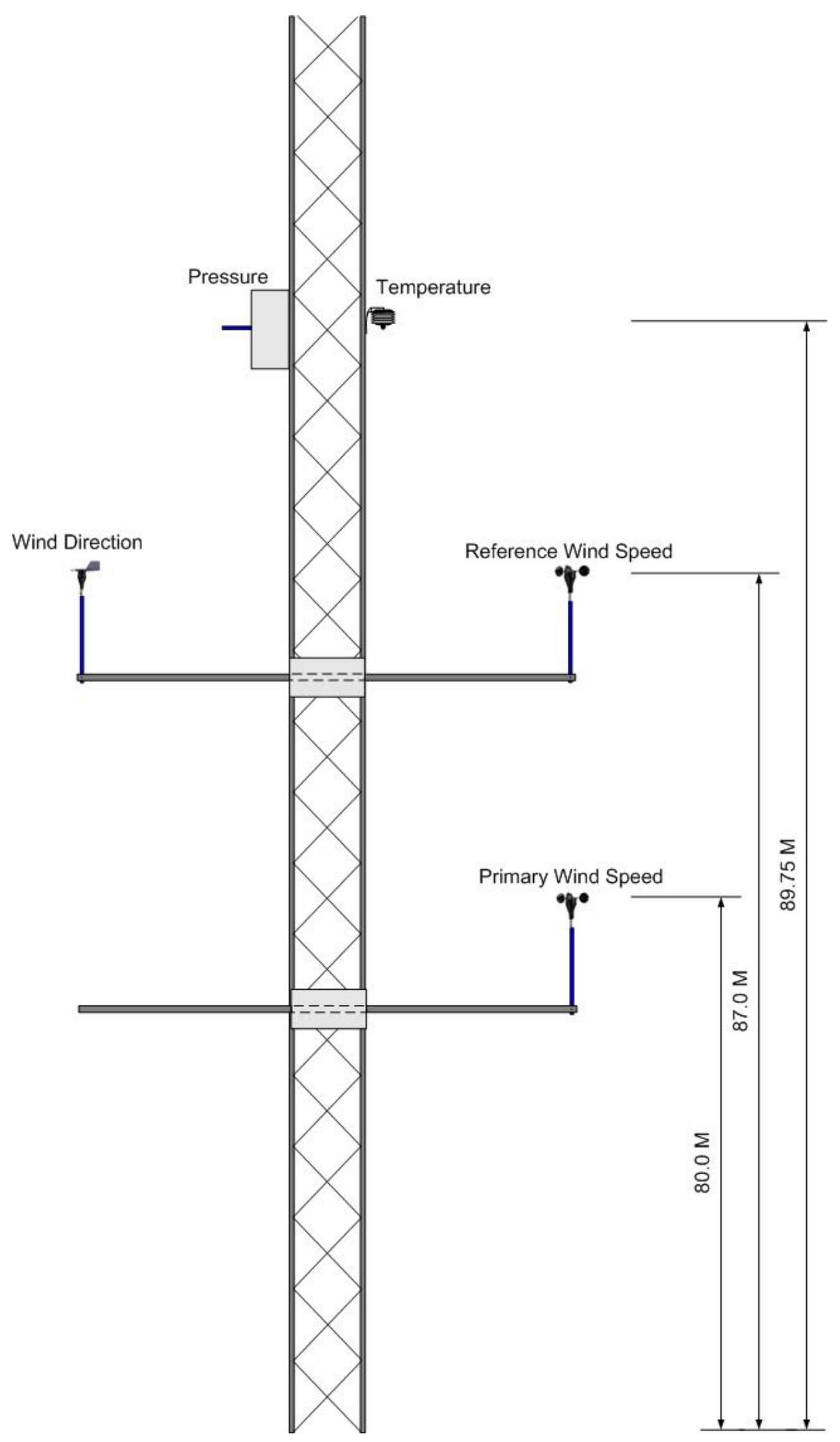

Figure 4. Meteorological (met) tower with instrument configuration. Illustration by Ismael Mendoza, NREL 
To ensure that only data obtained during normal operation of the turbine are used in the analysis, and to ensure that data are not corrupted, NREL excluded data sets from the database under the following circumstances:

- External conditions other than wind speed are out of the normal range for turbine operation.

- The turbine cannot operate because of a turbine fault condition.

- The turbine is manually shut down or in a test or maintenance operating mode.

- There is failure or maintenance of the data acquisition system

Two methods were used to track when any of these conditions occur during the test. In the first method, the logbook was checked for such events. The turbine supervisory control and data acquisition (SCADA) provided status signals to the data acquisition system that indicated when the turbine was available, braked, or faulted. In the second method, the status signal was checked in the data file during analysis. 


\section{Description of Test Procedure}

NREL conducted the test according to the procedures in the Standard. The sampling rate was $10 \mathrm{kHz}$, which was decimated to $40 \mathrm{~Hz}$ and then averaged over a 10-minute period. NREL also collected standard deviation, minimum, and maximum statistics for each averaging period.

Only database A is reported because the turbine did not reach cut-out wind speeds during the test period.

Table 5 gives the uncertainty sources and values used in the analysis. The uncertainty analysis was performed in accordance with the Standard. The Type A uncertainty in each wind speed bin is based on the standard deviation of the power values in the bin (Section E.4 of the Standard). The Type B uncertainties are related to the uncertainties in the instrumentation and flow distortion. The Type A and Type B uncertainties are combined to get the combined standard uncertainty.

Table 5. Uncertainty Values used in the Analysis

\begin{tabular}{|c|c|c|}
\hline Component & Uncertainty & Source \\
\hline \multicolumn{3}{|l|}{ Power } \\
\hline Power Transducer $^{a}$ & $0.869 \%$ & Calibration sheet \\
\hline Data Acquisition & $5.4 \mathrm{~kW}+0.075 \%$ & Specifications \\
\hline \multicolumn{3}{|l|}{ Wind Speed } \\
\hline Calibration & $0.0265 \mathrm{~m} / \mathrm{s}$ & Calibration sheet \\
\hline Operational Characteristics & $0.052 \mathrm{~m} / \mathrm{s}+0.52 \%$ & IEC equation (I.2) \\
\hline Mounting Effects & $2.50 \%$ & $\begin{array}{l}\text { Assumption due } \\
\text { to side-mounting }\end{array}$ \\
\hline Terrain Effects & $3.00 \%$ & $\begin{array}{l}\text { Assumption due } \\
\text { to no site calibration }\end{array}$ \\
\hline Data Acquisition & $0.002 \mathrm{~m} / \mathrm{s}$ & Assumption \\
\hline \multicolumn{3}{|l|}{ Temperature } \\
\hline Temperature Sensor & $0.150{ }^{\circ} \mathrm{C}$ & Calibration sheet \\
\hline Radiation Shielding & $0.200{ }^{\circ} \mathrm{C}$ & Assumption \\
\hline Mounting Effects & $0.138^{\circ} \mathrm{C}$ & IEC method \\
\hline Data Acquisition & $0.200{ }^{\circ} \mathrm{C}$ & Specifications \\
\hline \multicolumn{3}{|l|}{ Air Pressure } \\
\hline Pressure Sensor & $0.100 \mathrm{kPa}$ & Specifications \\
\hline Mounting Effects & $0.007 \mathrm{kPa}$ & IEC method \\
\hline Data Acquisition & $0.034 \mathrm{kPa}$ & Specifications \\
\hline
\end{tabular}

${ }^{a}$ Power transducer calibrated as single system. 


\section{Test Results}

\subsection{Tabular Results of Power Performance Test}

Table 6 through Table 9 provide the power performance test results in tabular format.

Table 6. Performance at Sea-Level Air Density, $1.225 \mathrm{~kg} / \mathrm{m} 3$

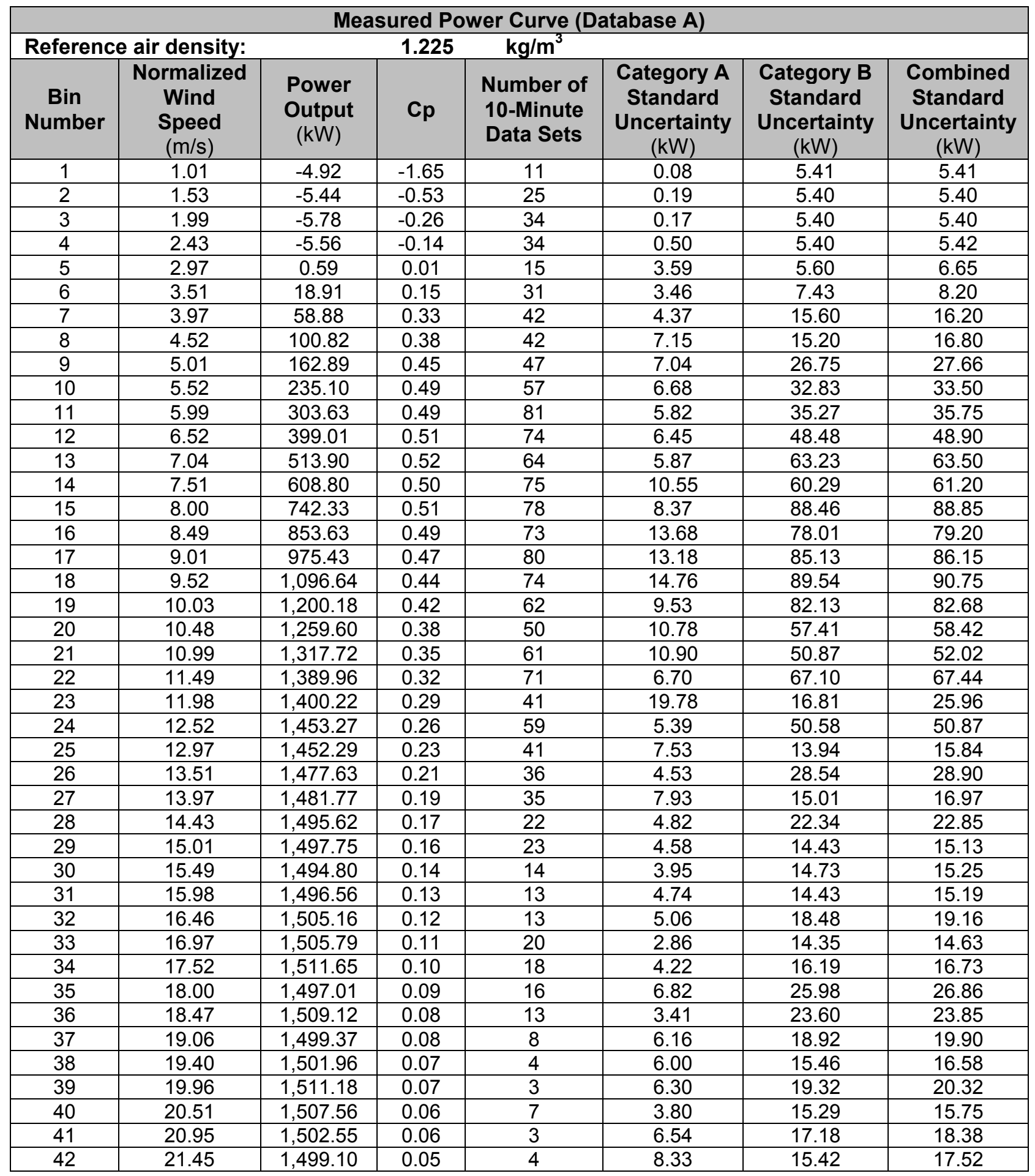


Table 7. Performance at Site Average Density, $1.00 \mathrm{~kg} / \mathrm{m} 3$

\begin{tabular}{|c|c|c|c|c|c|c|c|}
\hline \multicolumn{8}{|c|}{ Measured Power Curve (Database A) } \\
\hline \multicolumn{4}{|c|}{ Reference air density: } & \multicolumn{4}{|c|}{$\mathrm{kg} / \mathrm{m}^{3}$} \\
\hline $\begin{array}{c}\text { Bin } \\
\text { Number }\end{array}$ & $\begin{array}{c}\text { Normalized } \\
\text { Wind Speed } \\
(\mathrm{m} / \mathrm{s})\end{array}$ & $\begin{array}{c}\text { Power } \\
\text { Output } \\
\text { (kW) }\end{array}$ & Cp & $\begin{array}{c}\text { Number } \\
\text { of } \\
\text { 10-Minute } \\
\text { Data Sets }\end{array}$ & $\begin{array}{c}\text { Category A } \\
\text { Standard } \\
\text { Uncertainty } \\
\text { (kW) }\end{array}$ & $\begin{array}{c}\text { Category B } \\
\text { Standard } \\
\text { Uncertainty } \\
\text { (kW) }\end{array}$ & $\begin{array}{c}\text { Combined } \\
\text { Standard } \\
\text { Uncertainty } \\
(\mathrm{kW})\end{array}$ \\
\hline 1 & 1.06 & -4.92 & -1.77 & 10 & 0.09 & 5.41 & 5.41 \\
\hline 2 & 1.50 & -5.22 & -0.66 & 15 & 0.19 & 5.40 & 5.40 \\
\hline 3 & 1.97 & -5.78 & -0.32 & 35 & 0.18 & 5.40 & 5.40 \\
\hline 4 & 2.49 & -5.74 & -0.16 & 38 & 0.43 & 5.40 & 5.42 \\
\hline 5 & 3.01 & 0.38 & 0.01 & 17 & 3.14 & 5.62 & 6.44 \\
\hline 6 & 3.60 & 7.91 & 0.07 & 19 & 3.90 & 5.75 & 6.95 \\
\hline 7 & 4.02 & 41.48 & 0.27 & 39 & 4.21 & 14.52 & 15.11 \\
\hline 8 & 4.49 & 72.51 & 0.34 & 32 & 6.50 & 13.32 & 14.82 \\
\hline 9 & 5.01 & 120.45 & 0.41 & 45 & 8.01 & 19.72 & 21.28 \\
\hline 10 & 5.54 & 186.64 & 0.47 & 46 & 5.29 & 29.01 & 29.49 \\
\hline 11 & 6.03 & 245.79 & 0.48 & 56 & 7.56 & 30.18 & 31.11 \\
\hline 12 & 6.49 & 316.77 & 0.50 & 75 & 4.88 & 41.04 & 41.33 \\
\hline 13 & 7.01 & 407.67 & 0.51 & 68 & 6.38 & 49.29 & 49.70 \\
\hline 14 & 7.53 & 516.00 & 0.52 & 61 & 5.93 & 63.28 & 63.56 \\
\hline 15 & 8.02 & 605.60 & 0.50 & 71 & 11.11 & 59.70 & 60.72 \\
\hline 16 & 8.51 & 725.58 & 0.51 & 73 & 7.70 & 83.83 & 84.18 \\
\hline 17 & 8.99 & 831.26 & 0.49 & 68 & 14.16 & 79.32 & 80.58 \\
\hline 18 & 9.48 & 961.48 & 0.48 & 67 & 10.22 & 100.91 & 101.42 \\
\hline 19 & 9.98 & $1,030.57$ & 0.45 & 72 & 18.34 & 55.86 & 58.79 \\
\hline 20 & 10.48 & $1,167.87$ & 0.44 & 60 & 8.75 & 115.29 & 115.62 \\
\hline 21 & 10.98 & $1,227.96$ & 0.40 & 63 & 9.78 & 53.79 & 54.67 \\
\hline 22 & 11.54 & $1,291.73$ & 0.36 & 51 & 12.52 & 54.09 & 55.52 \\
\hline 23 & 12.02 & $1,358.14$ & 0.34 & 57 & 8.47 & 66.40 & 66.94 \\
\hline 24 & 12.47 & $1,403.64$ & 0.31 & 59 & 8.17 & 52.68 & 53.31 \\
\hline 25 & 13.01 & $1,407.81$ & 0.27 & 39 & 20.16 & 14.10 & 24.60 \\
\hline 26 & 13.51 & $1,459.32$ & 0.25 & 55 & 4.76 & 57.13 & 57.32 \\
\hline 27 & 13.96 & $1,451.06$ & 0.23 & 36 & 8.24 & 17.09 & 18.97 \\
\hline 28 & 14.51 & $1,479.57$ & 0.21 & 32 & 4.67 & 33.25 & 33.58 \\
\hline 29 & 14.95 & $1,482.17$ & 0.19 & 34 & 8.15 & 14.56 & 16.68 \\
\hline 30 & 15.42 & $1,493.91$ & 0.17 & 21 & 4.72 & 20.84 & 21.36 \\
\hline 31 & 16.02 & $1,500.60$ & 0.16 & 22 & 4.61 & 15.93 & 16.59 \\
\hline 32 & 16.44 & $1,489.06$ & 0.14 & 12 & 5.05 & 22.82 & 23.37 \\
\hline 33 & 16.99 & $1,499.79$ & 0.13 & 15 & 4.27 & 19.39 & 19.86 \\
\hline 34 & 17.50 & $1,504.21$ & 0.12 & 12 & 5.51 & 15.53 & 16.48 \\
\hline 35 & 18.07 & $1,506.73$ & 0.11 & 18 & 3.20 & 14.68 & 15.02 \\
\hline 36 & 18.55 & $1,507.27$ & 0.10 & 15 & 3.75 & 14.36 & 14.84 \\
\hline 37 & 19.00 & $1,504.36$ & 0.09 & 17 & 4.11 & 15.11 & 15.66 \\
\hline 38 & 19.54 & $1,500.59$ & 0.09 & 14 & 7.94 & 15.25 & 17.19 \\
\hline 39 & 19.90 & $1,512.63$ & 0.08 & 7 & 4.75 & 30.04 & 30.41 \\
\hline 40 & 20.48 & $1,501.23$ & 0.08 & 9 & 5.83 & 21.47 & 22.25 \\
\hline 41 & 20.98 & $1,495.36$ & 0.07 & 3 & 2.21 & 17.19 & 17.33 \\
\hline 42 & 21.55 & $1,514.39$ & 0.06 & 3 & 3.40 & 31.76 & 31.94 \\
\hline 43 & 22.02 & $1,506.40$ & 0.06 & 7 & 3.91 & 20.66 & 21.03 \\
\hline 44 & 22.50 & $1,503.50$ & 0.06 & 2 & 3.91 & 20.66 & 21.03 \\
\hline 45 & 22.95 & $1,499.10$ & 0.05 & 4 & 8.33 & 16.81 & 18.76 \\
\hline
\end{tabular}


Table 8. Annual Energy Production (AEP) at Sea-Level Density, $1.225 \mathrm{~kg} / \mathrm{m}^{3}$

\begin{tabular}{|c|c|c|c|c|c|}
\hline \multicolumn{6}{|c|}{ Estimated AEP, Database A (all valid data) } \\
\hline & $\begin{array}{l}\text { Reference air density: } \\
\text { Cut-out wind speed: }\end{array}$ & $\begin{array}{l}1.225 \\
25.00\end{array}$ & $\begin{array}{l}\mathrm{kg} / \mathrm{m}^{3} \\
\mathrm{~m} / \mathrm{s}\end{array}$ & & \\
\hline \multirow{2}{*}{$\begin{array}{c}\text { Hub Height } \\
\text { Annual Average } \\
\text { Wind Speed } \\
\text { (Rayleigh) } \\
\text { m/s }\end{array}$} & \multirow{2}{*}{$\begin{array}{l}\text { AEP Measured } \\
\text { MWh }\end{array}$} & \multicolumn{2}{|c|}{$\begin{array}{c}\text { Standard } \\
\text { Uncertainty in } \\
\text { AEP Measured }\end{array}$} & \multirow{2}{*}{$\begin{array}{c}\text { AEP } \\
\text { Extrapolated } \\
\text { MWh }\end{array}$} & \multirow[t]{2}{*}{$\begin{array}{l}\text { Complete if } \\
\text { AEP } \\
\text { Measured is at } \\
\text { Least } 95 \% \text { of } \\
\text { AEP } \\
\text { Extrapolated }\end{array}$} \\
\hline & & MWh & $\%$ & & \\
\hline 4 & 1,322 & 198 & $15 \%$ & 1,322 & Complete \\
\hline 5 & 2,491 & 281 & $11 \%$ & 2,491 & Complete \\
\hline 6 & 3,767 & 336 & $9 \%$ & 3,768 & Complete \\
\hline 7 & 4,990 & 363 & $7 \%$ & 4,997 & Complete \\
\hline 8 & 6,056 & 369 & $6 \%$ & 6,096 & Complete \\
\hline 9 & 6,905 & 362 & $5 \%$ & 7,026 & Complete \\
\hline 10 & 7,513 & 347 & $5 \%$ & 7,770 & Complete \\
\hline 11 & 7,886 & 329 & $4 \%$ & 8,321 & Incomplete \\
\hline 1 & $\begin{array}{l}\text { ed assumes z } \\
\text { ted assumes }\end{array}$ & Wer & $\begin{array}{l}\text { een } \\
\text { be }\end{array}$ & $\begin{array}{l}\text { bin and cu } \\
\text { t bin and }\end{array}$ & \\
\hline
\end{tabular}

Table 9. Annual Energy Production at Site Average Density, $1.00 \mathrm{~kg} / \mathrm{m}^{3}$

\begin{tabular}{|c|c|c|c|c|c|}
\hline \multicolumn{6}{|c|}{ Estimated AEP, Database A (all valid data) } \\
\hline & $\begin{array}{r}\text { Reference air } \\
\text { density: } \\
\text { Cut-out wind speed: }\end{array}$ & $\begin{array}{l}1.00 \\
25.0\end{array}$ & $\begin{array}{l}\mathrm{kg} / \mathrm{m}^{3} \\
\mathrm{~m} / \mathrm{s}\end{array}$ & & \\
\hline \multirow{2}{*}{$\begin{array}{c}\text { Hub Height } \\
\text { Annual } \\
\text { Average Wind } \\
\text { Speed } \\
\text { (Rayleigh) } \\
\text { m/s }\end{array}$} & \multirow{2}{*}{$\begin{array}{l}\text { AEP Measured } \\
\text { MWh }\end{array}$} & \multicolumn{2}{|c|}{$\begin{array}{c}\text { Standard } \\
\text { Uncertainty in } \\
\text { AEP Measured }\end{array}$} & \multirow{2}{*}{$\begin{array}{c}\text { AEP } \\
\text { Extrapolated } \\
\text { MWh }\end{array}$} & \multirow[t]{2}{*}{$\begin{array}{l}\text { Complete if AEP } \\
\text { Measured is at } \\
\text { Least } 95 \% \text { of AEP } \\
\text { Extrapolated }\end{array}$} \\
\hline & & MWh & $\%$ & & \\
\hline 4 & 1,057 & 174 & $16 \%$ & 1,057 & Complete \\
\hline 5 & 2,085 & 255 & $12 \%$ & 2,085 & Complete \\
\hline 6 & 3,264 & 318 & $10 \%$ & 3,264 & Complete \\
\hline 7 & 4,443 & 354 & $8 \%$ & 4,445 & Complete \\
\hline 8 & 5,521 & 369 & $7 \%$ & 5,536 & Complete \\
\hline 9 & 6,433 & 369 & $6 \%$ & 6,482 & Complete \\
\hline 10 & 7,143 & 361 & $5 \%$ & 7,256 & Complete \\
\hline 11 & 7,640 & 347 & $5 \%$ & 7,843 & Complete \\
\hline
\end{tabular}




\subsection{Graphical Results Power Performance Test}

Figure 5 through Figure 11 show the graphical results of the power performance test. Figure 5 shows a plot of the binned power curve normalized to sea-level air density.

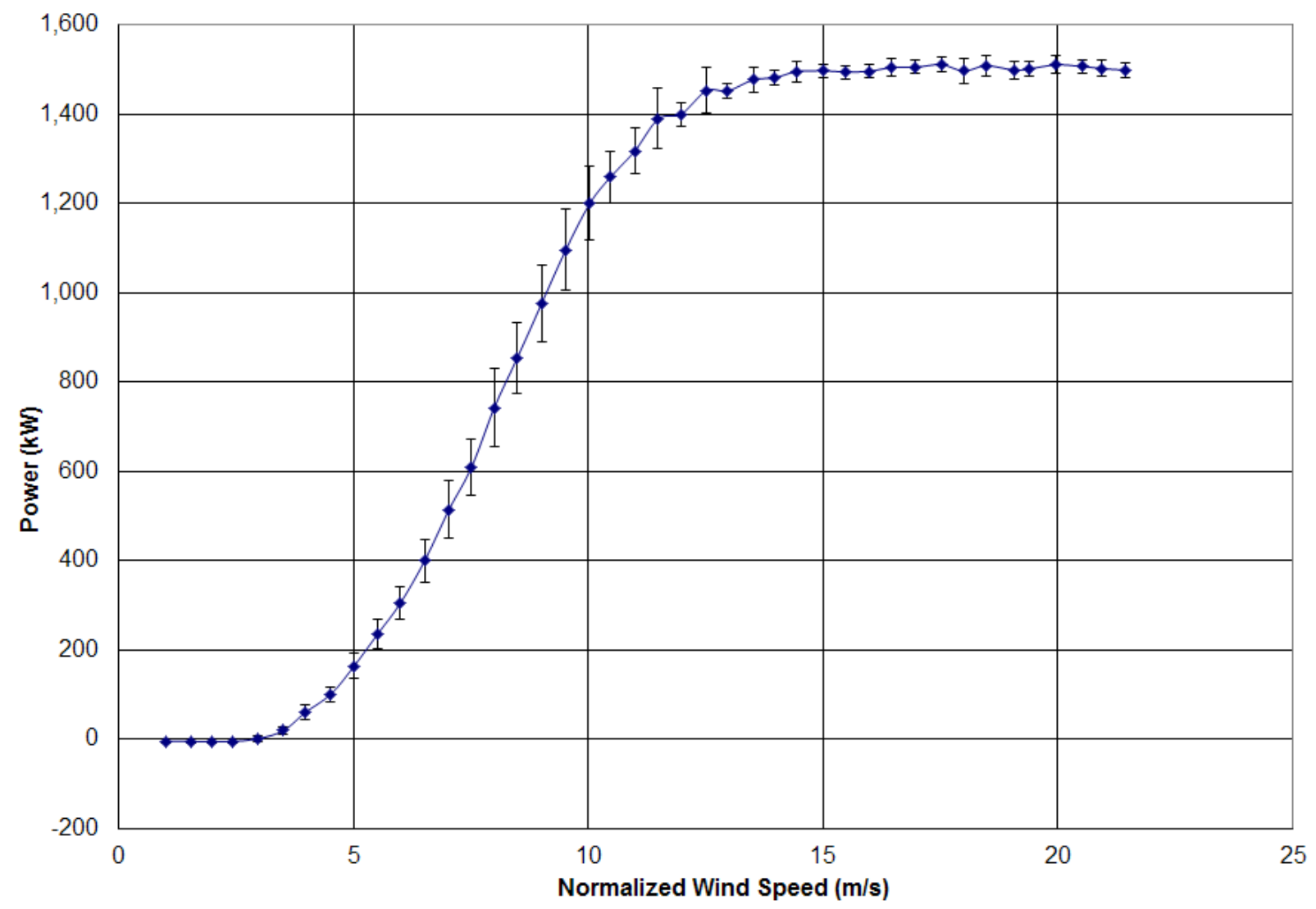

Figure 5. Power curve at sea-level air density, $1.225 \mathrm{~kg} / \mathrm{m}^{3}$

Figure 6 shows a plot of the binned power curve at the site average air density during the test period. 


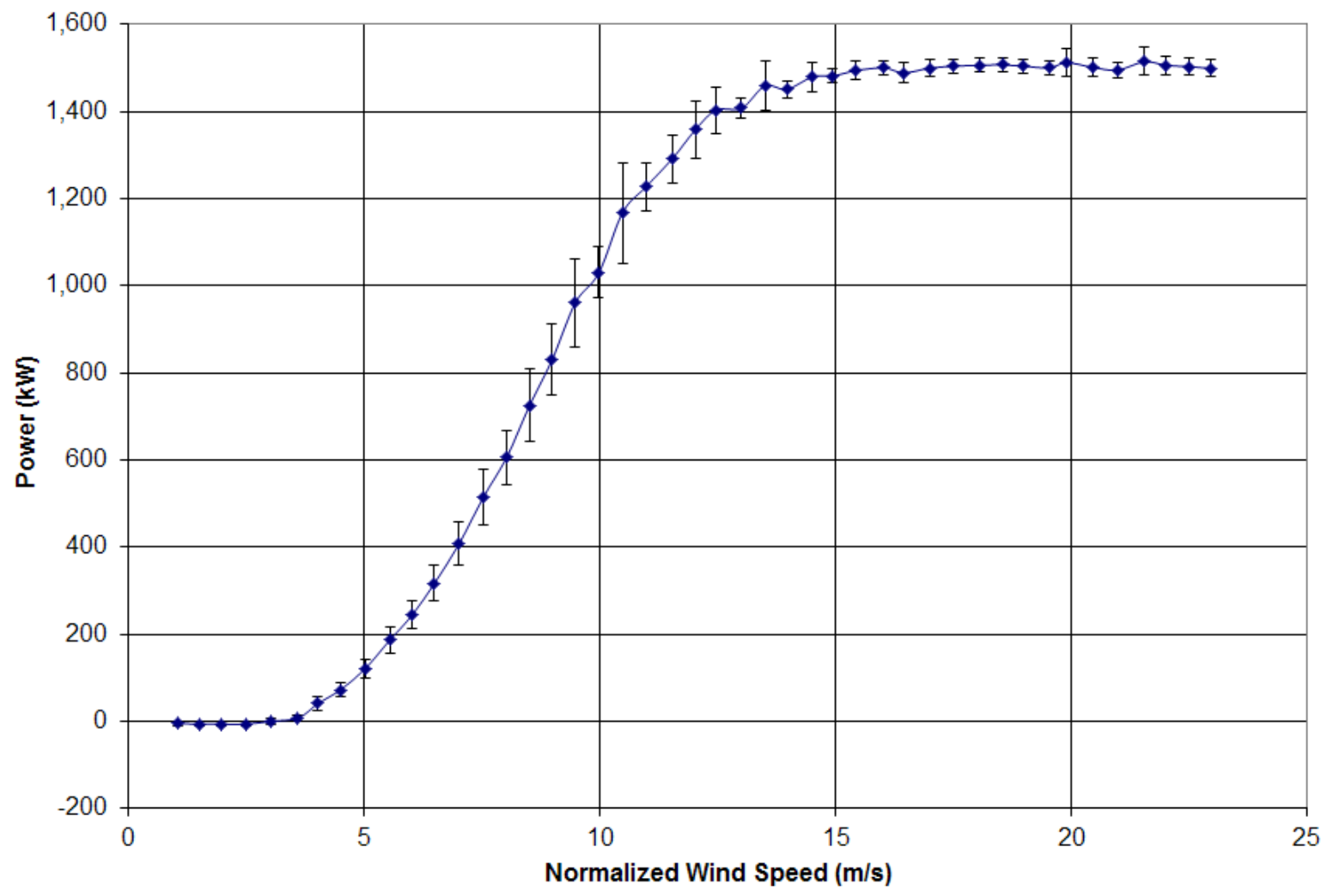

Figure 6. Power curve at site average air density, $1.00 \mathrm{~kg} / \mathrm{m}^{3}$

Figure 7 shows a scatterplot of the turbine power statistics as a function of site average normalized wind speed. 


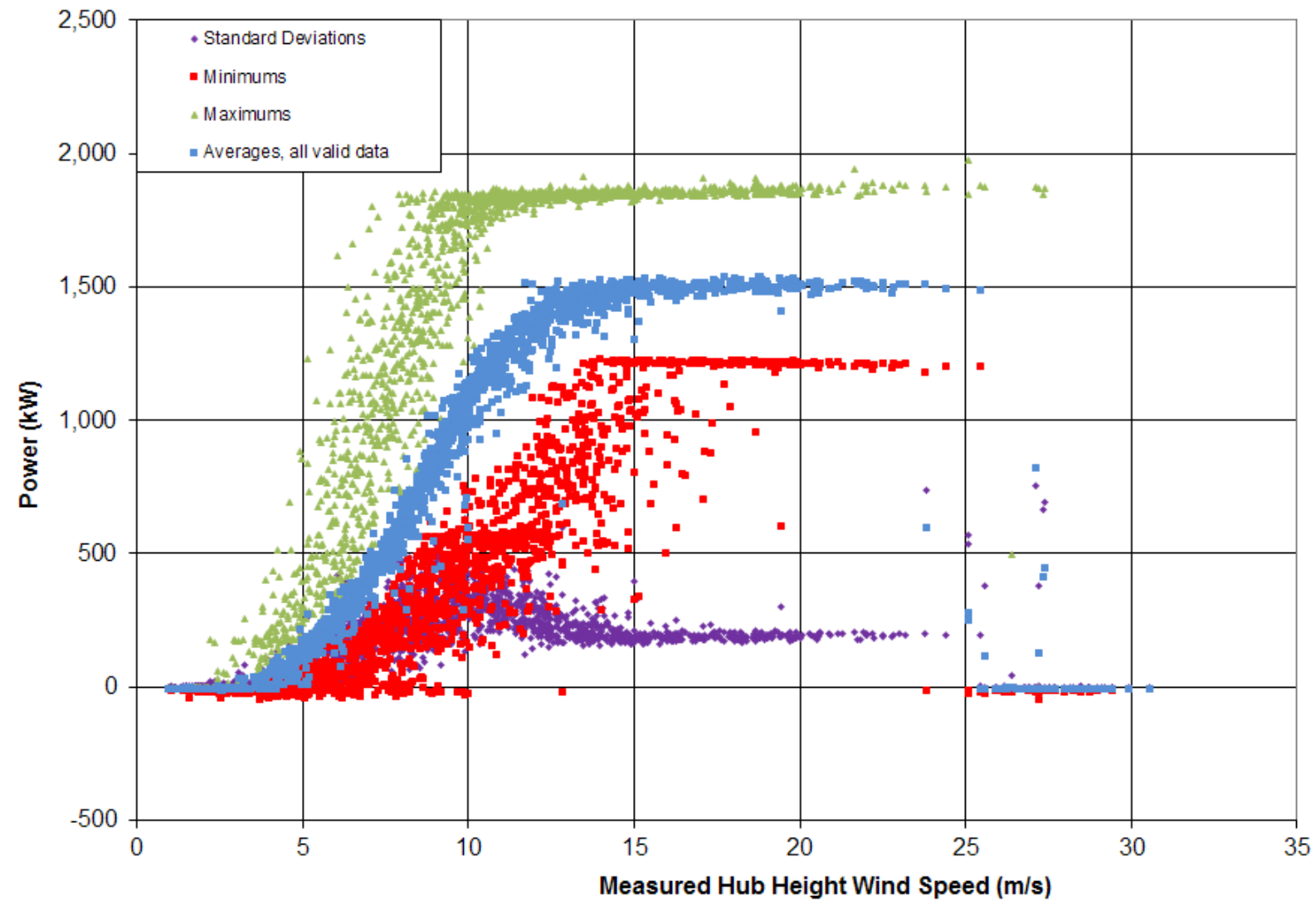

Figure 7. Scatterplot averages, standard deviation, minimum, maximum power as a function of wind speed normalized to site average air density, $1.00 \mathrm{~kg} / \mathrm{m}^{3}$

Figure 8 shows a plot of the binned coefficient of performance as a function of wind speed at sea-level normalized air density. 


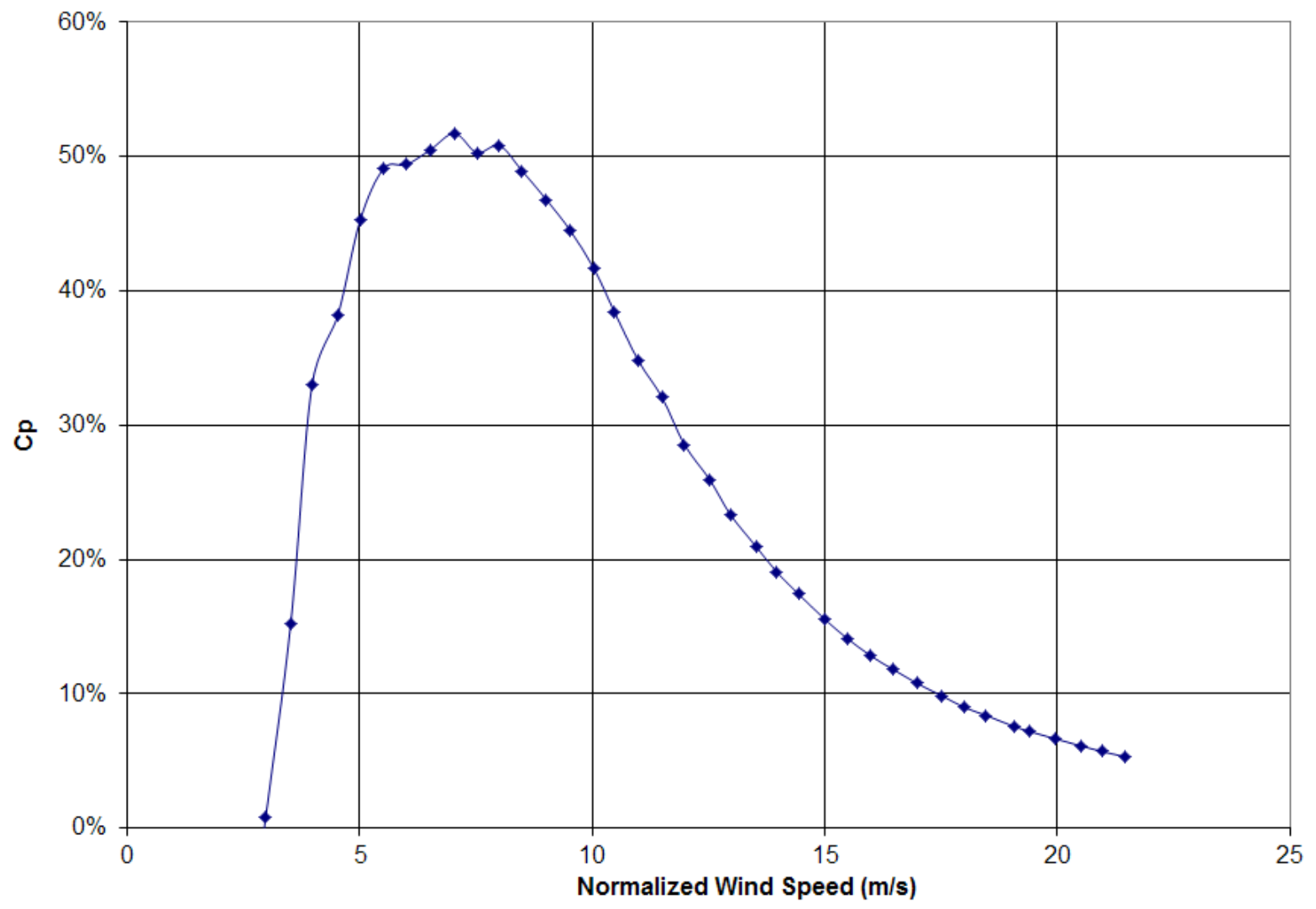

Figure 8. Coefficient of performance at sea-level air density, $1.225 \mathrm{~kg} / \mathrm{m}^{3}$, with turbine rotor swept area $=4,656.63 \mathrm{~m}^{2}$

Figure 9 shows a plot of the binned coefficient of performance as a function of wind speed normalized to site-specific air density. 


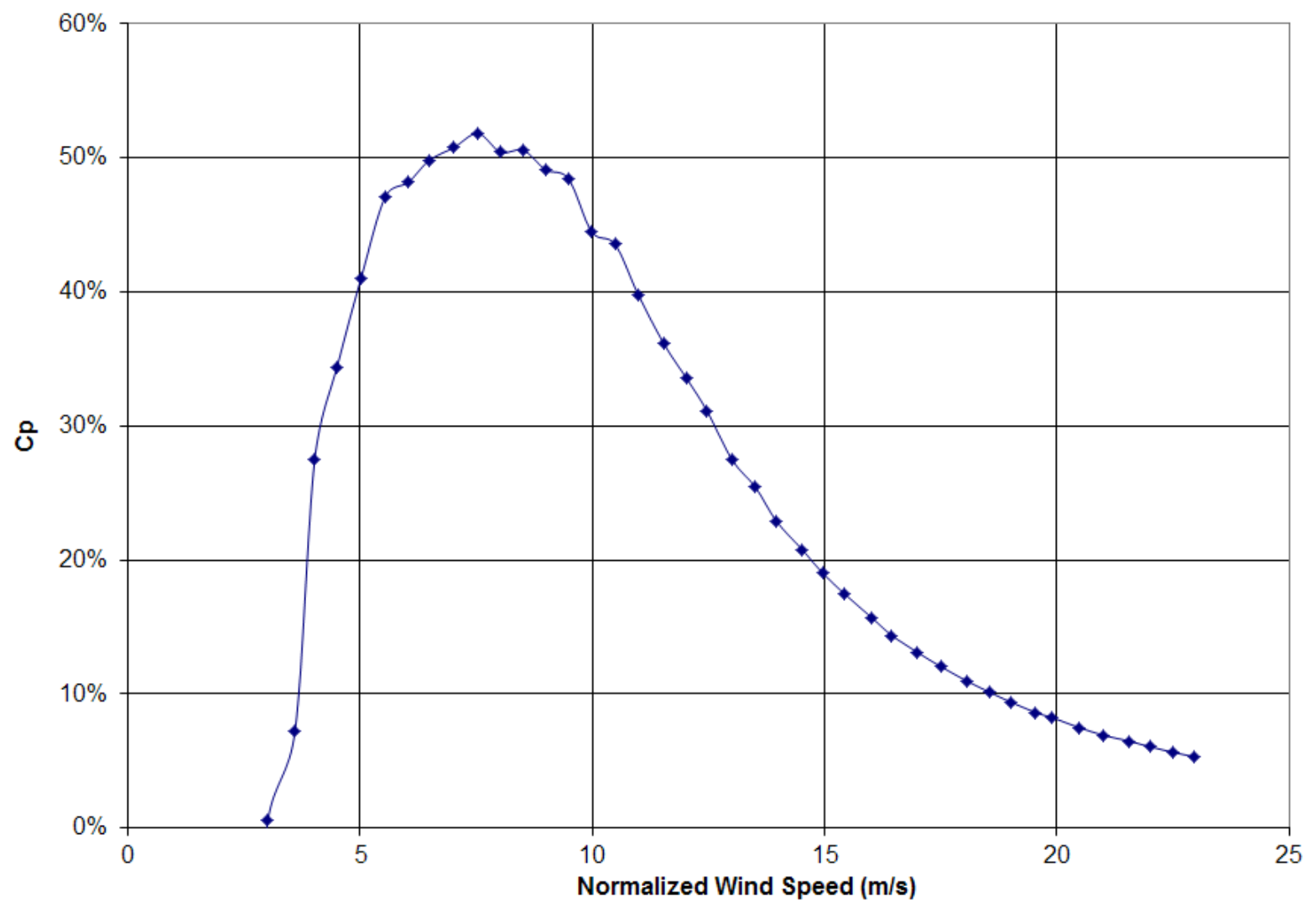

Figure 9. Coefficient of performance at site average air density, $1.00 \mathrm{~kg} / \mathrm{m}^{3}$, with turbine rotor swept area $=4,656.63 \mathrm{~m}^{2}$

Figure 10 shows a scatterplot of average wind speed and turbulence intensity as a function of wind direction. 


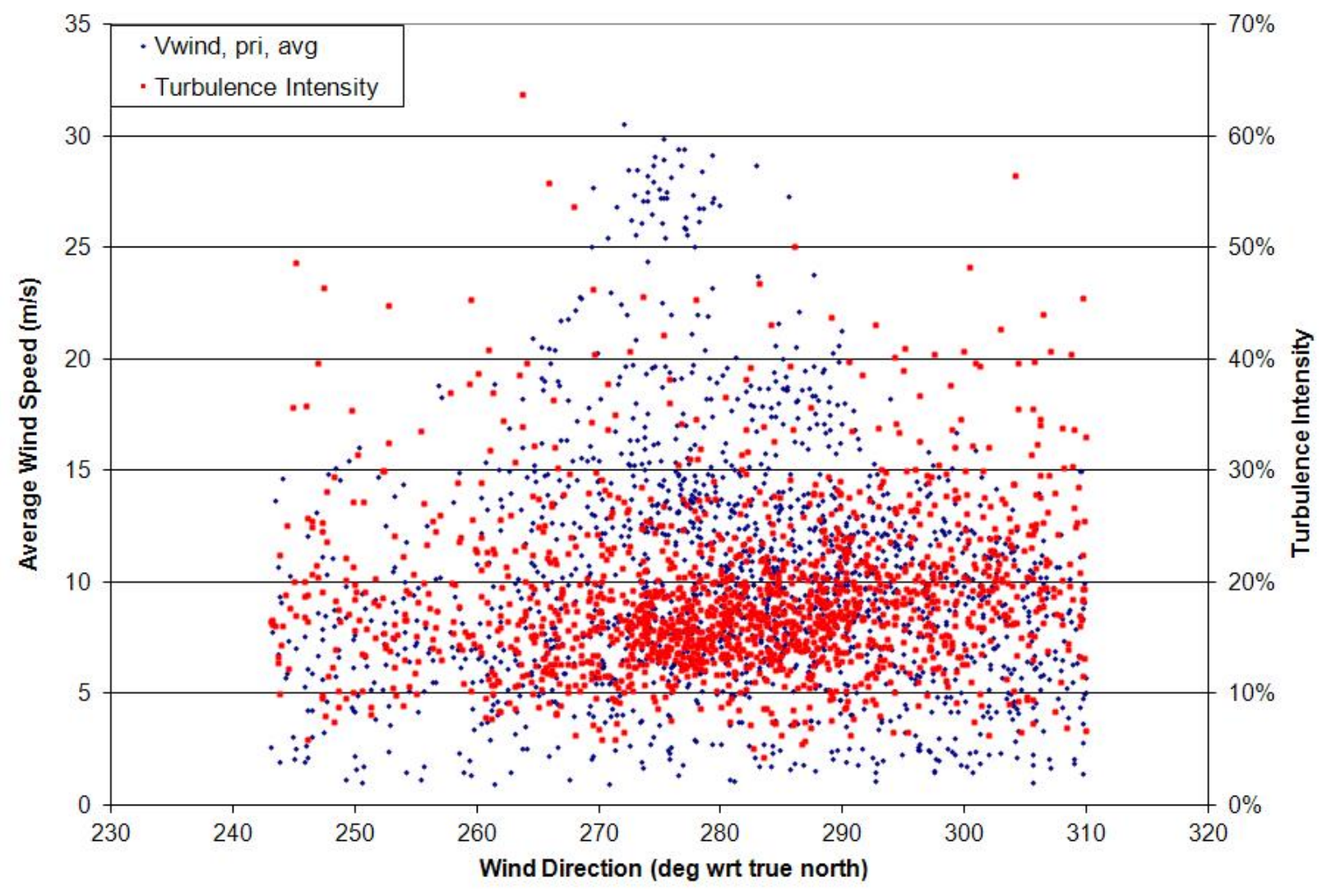

Figure 10. Wind speed and turbulence intensity as a function of wind direction

Figure 11 shows a scatterplot and binned turbulence intensity as a function of wind speed. 


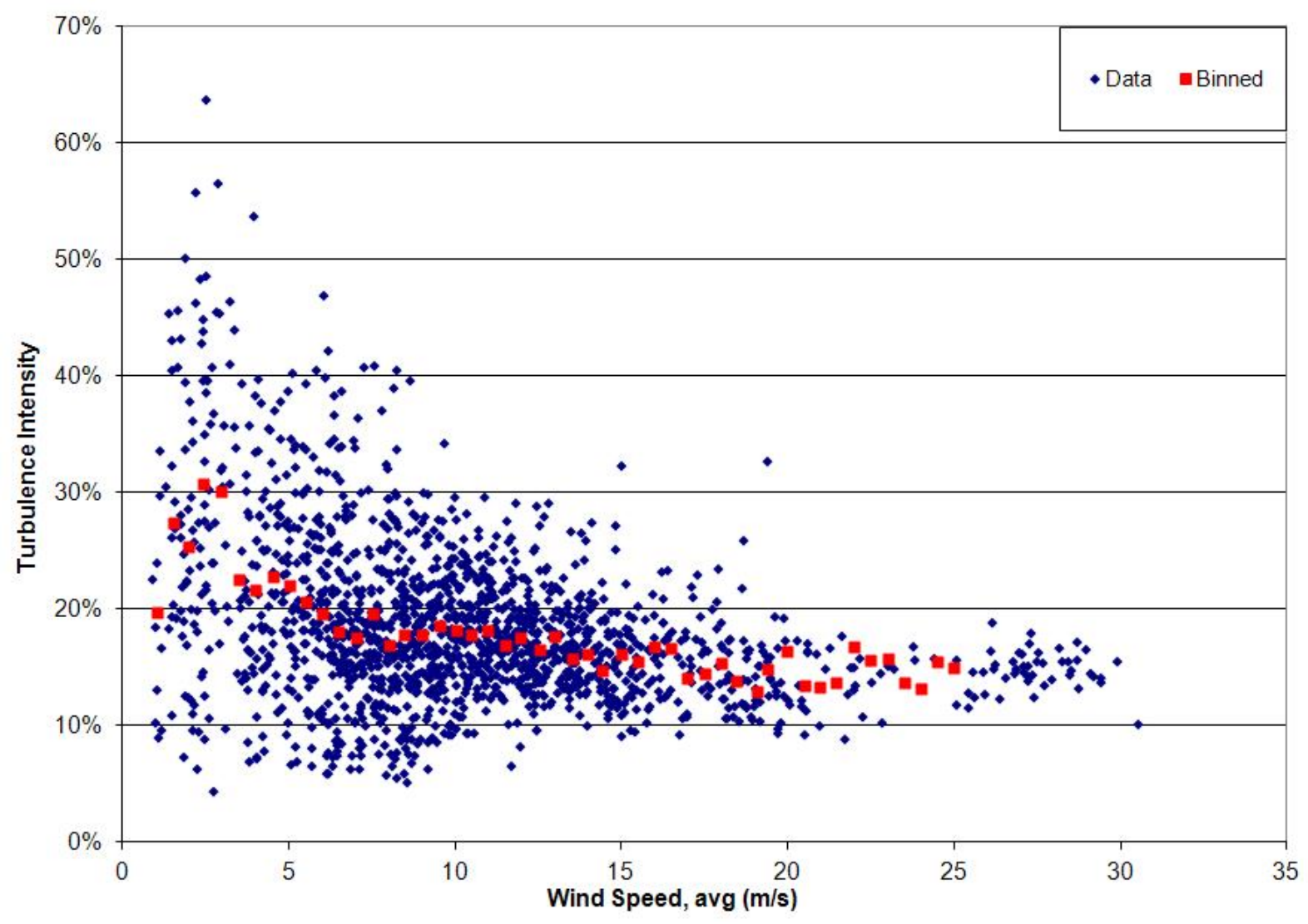

Figure 11. Wind turbulence as a function of wind speed 


\section{Exceptions}

\subsection{Exceptions to the Standard}

Two exceptions to the Standard were identified:

- The test site did not pass the site assessment as per Annex A of the Standard. The area to the east of the turbine within 5 rotor diameters has a terrain variation greater than the allowed maximum variation from the best fit plane. The Standard requires that a site calibration be performed if the site assessment fails; however, the client and NREL decided not to perform a site calibration. Additional uncertainty has been included in the analysis for flow distortion caused by the terrain.

- Because of the requirement for a 135-m met tower for subsequent activities, the hub height anemometer was not top-mounted but on a side boom at $80 \mathrm{~m}$ in a configuration not recommended by the Standard. Additional uncertainty has been included in the analysis for mounting effects on the anemometer.

\subsection{Exceptions to the Test Plan}

No exceptions were taken to the test plan.

\subsubsection{Exceptions to NREL's Quality System}

No exceptions were taken to NREL's quality system. 


\section{References}

1. International Electrotechnical Commission (IEC). (2005). "Wind Turbines - Part 12-1: Power Performance Measurements of Electricity Producing Wind Turbines." TS IEC 61400-13. First edition, 2005-12. 


\section{Appendix A. Pictures of Test Site}

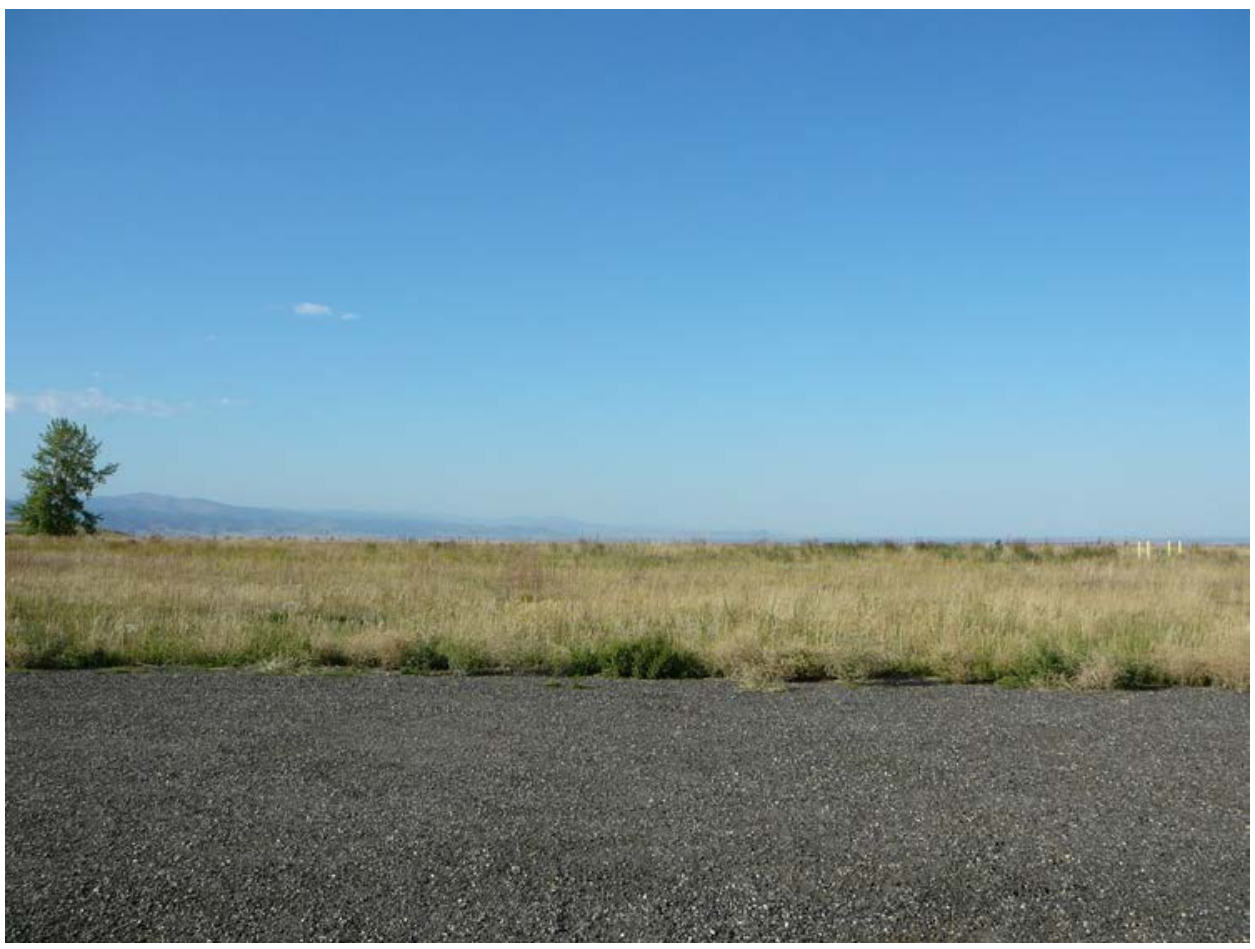

Figure A-1. At the base of the tower facing north. Photo by Ismael Mendoza, NREL

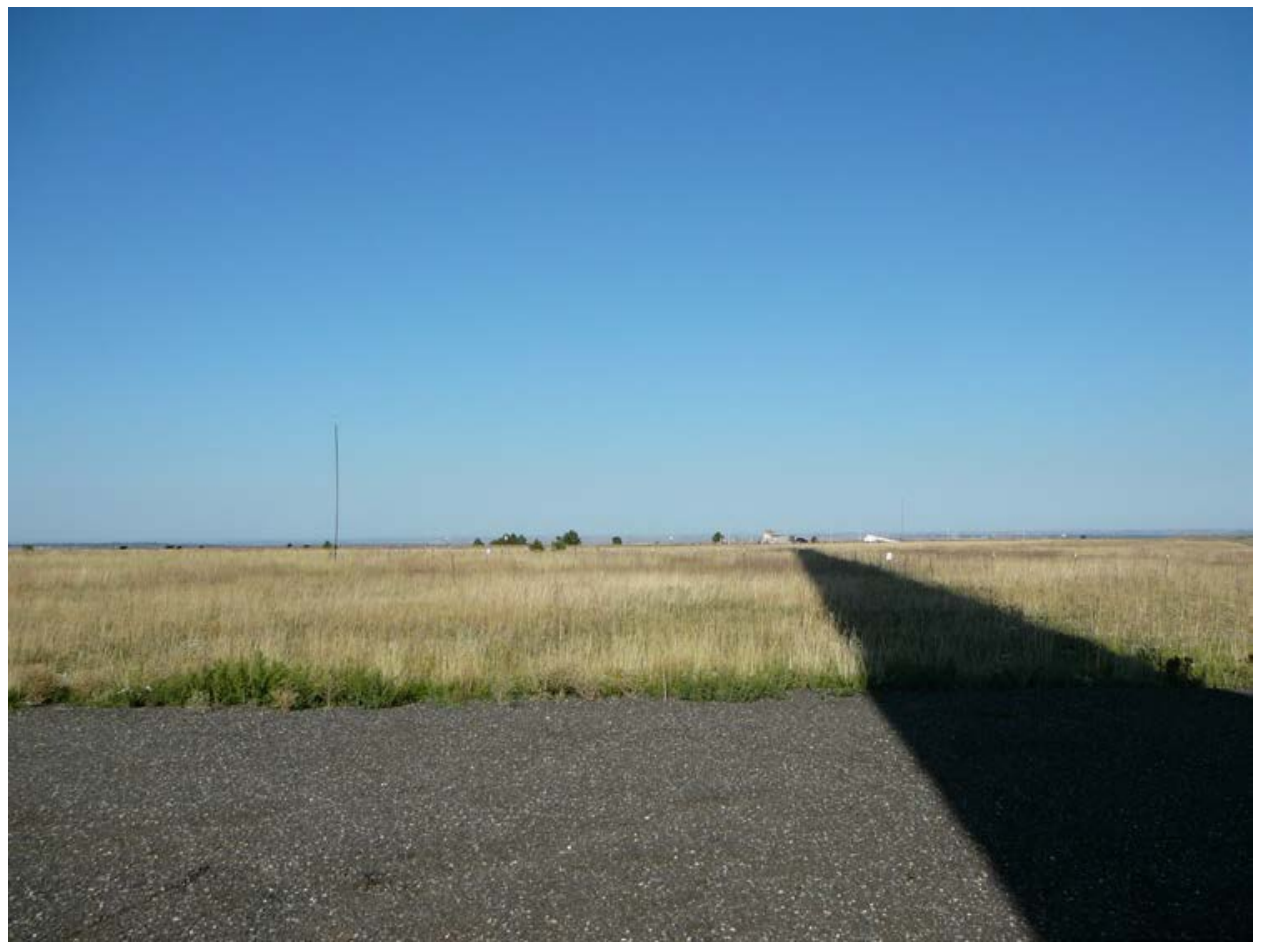

Figure A-2. At the base of the tower facing northeast. Photo by Ismael Mendoza, NREL 


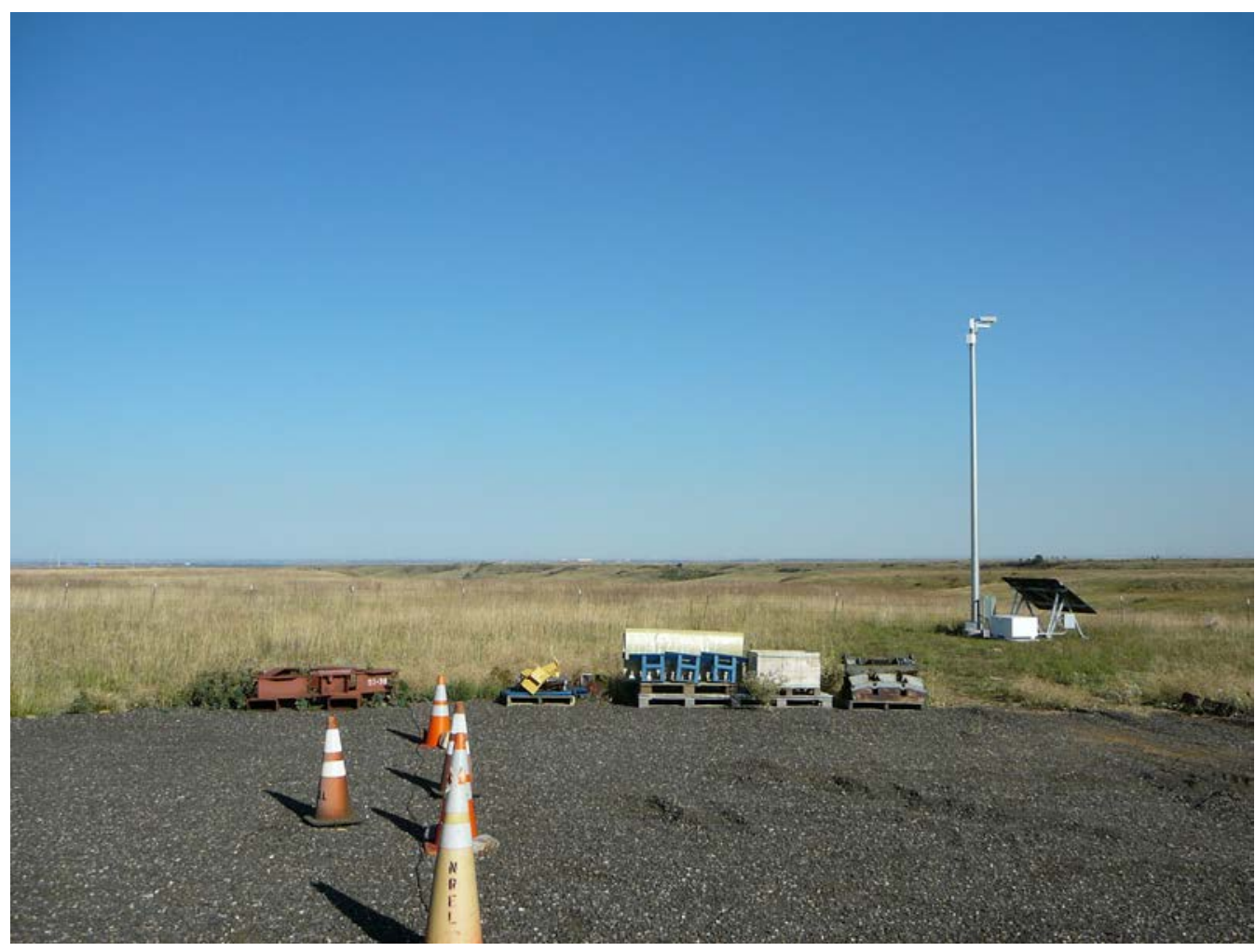

Figure A-3. At the base of the tower facing east. Photo by Ismael Mendoza, NREL

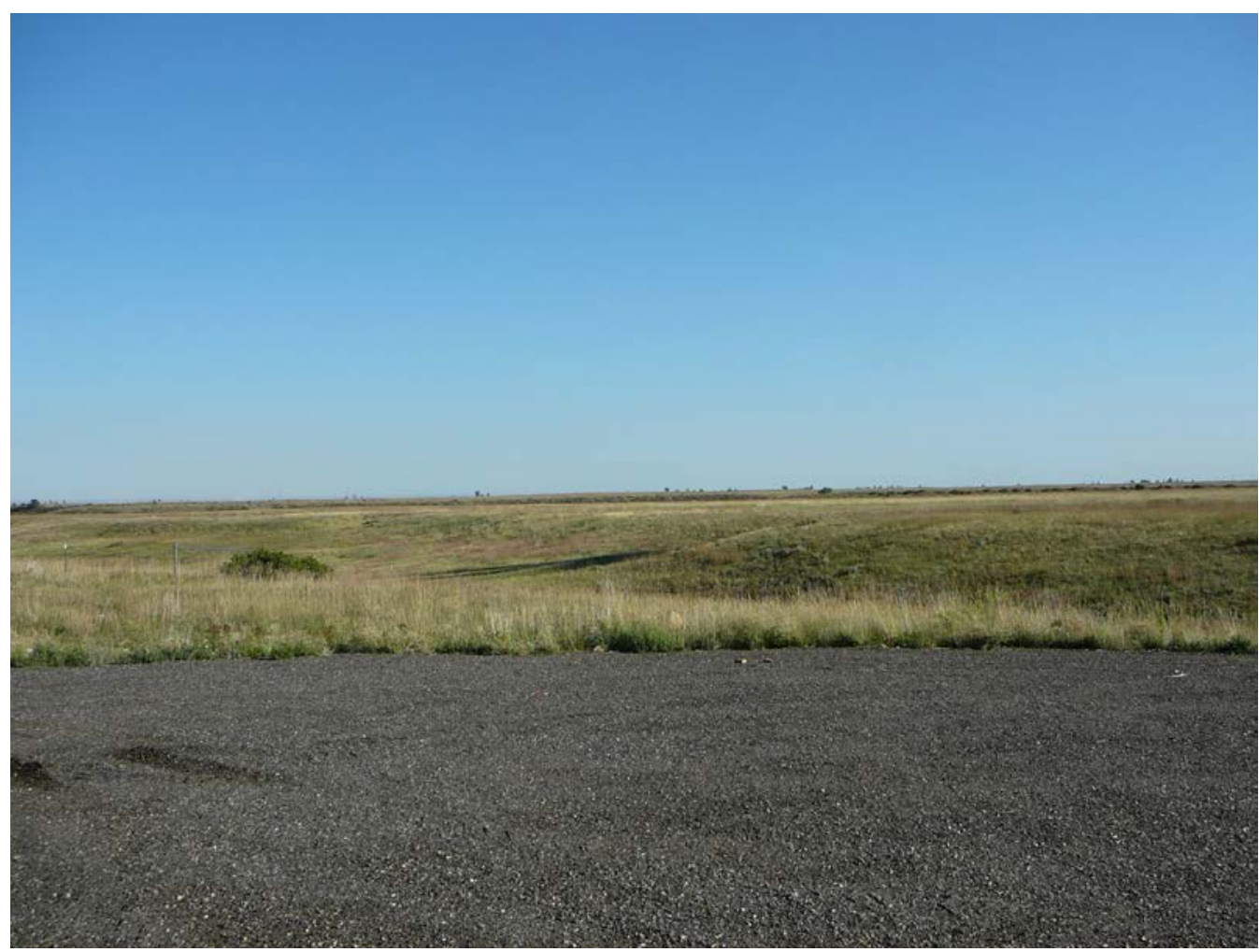

Figure A-4. At the base of the tower facing southeast. Photo by Ismael Mendoza, NREL 


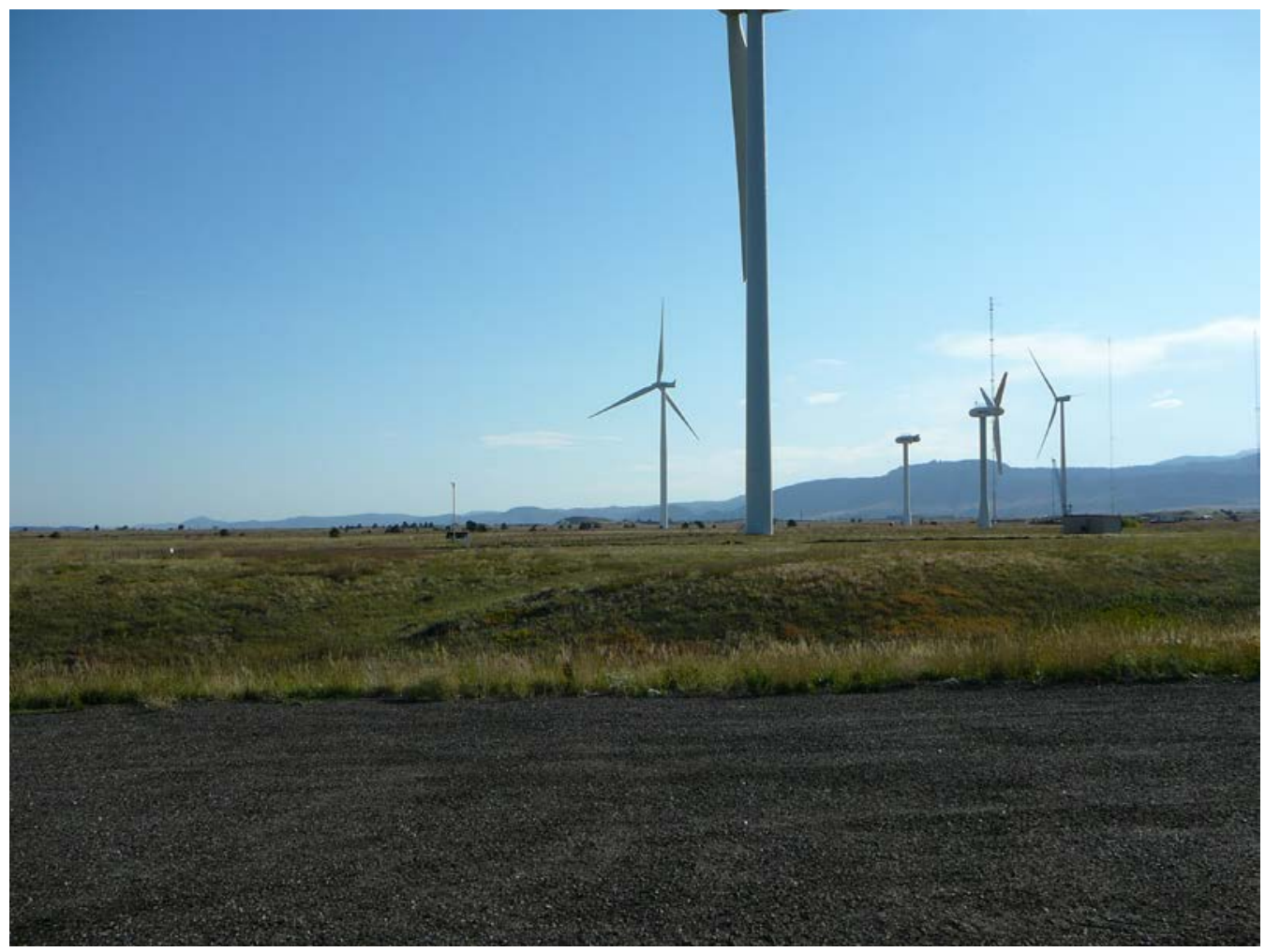

Figure A-5. At the base of the tower facing south. Photo by Ismael Mendoza, NREL

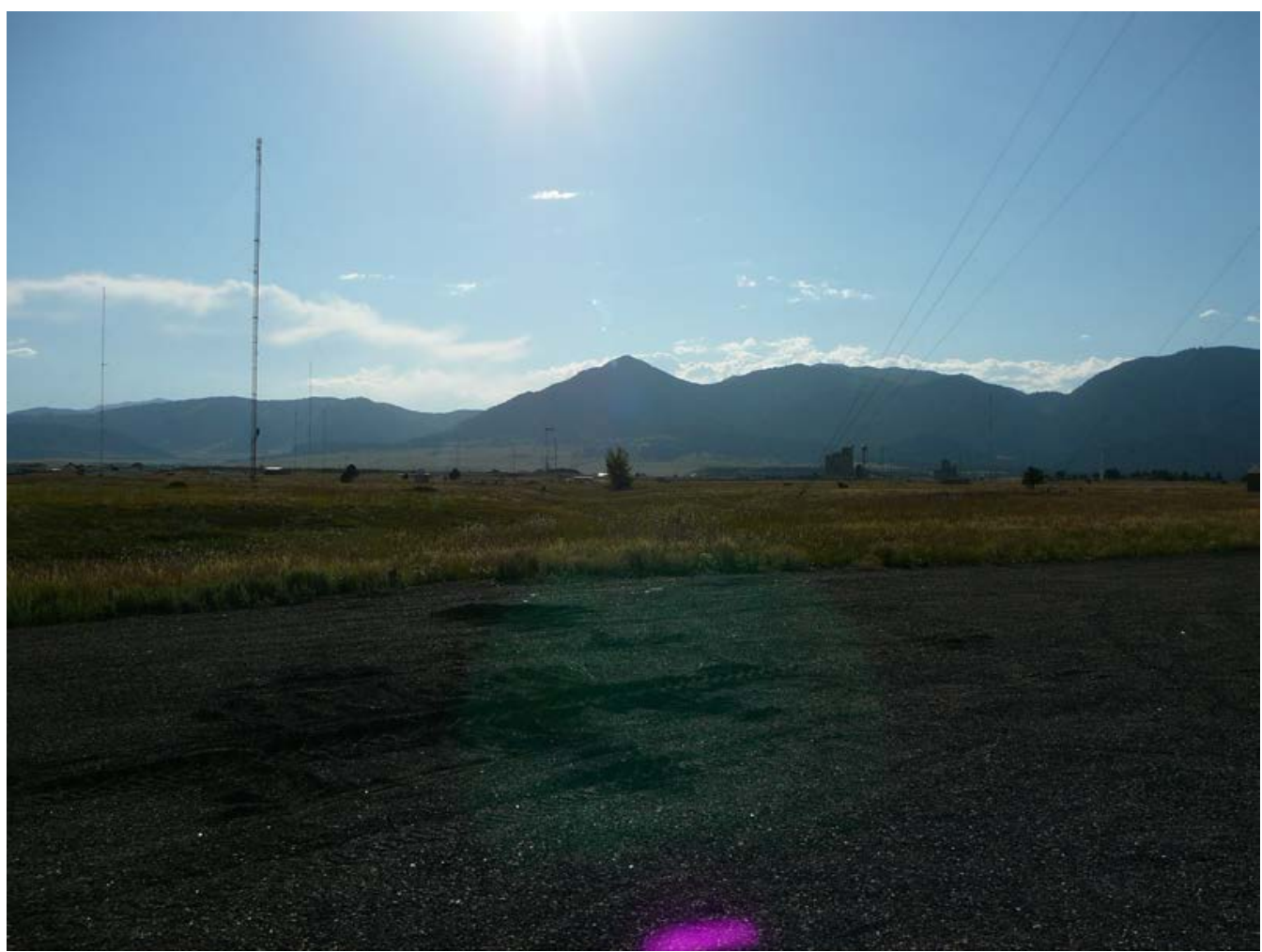

Figure A-6. At the base of the tower facing southwest. Photo by Ismael Mendoza, NREL 


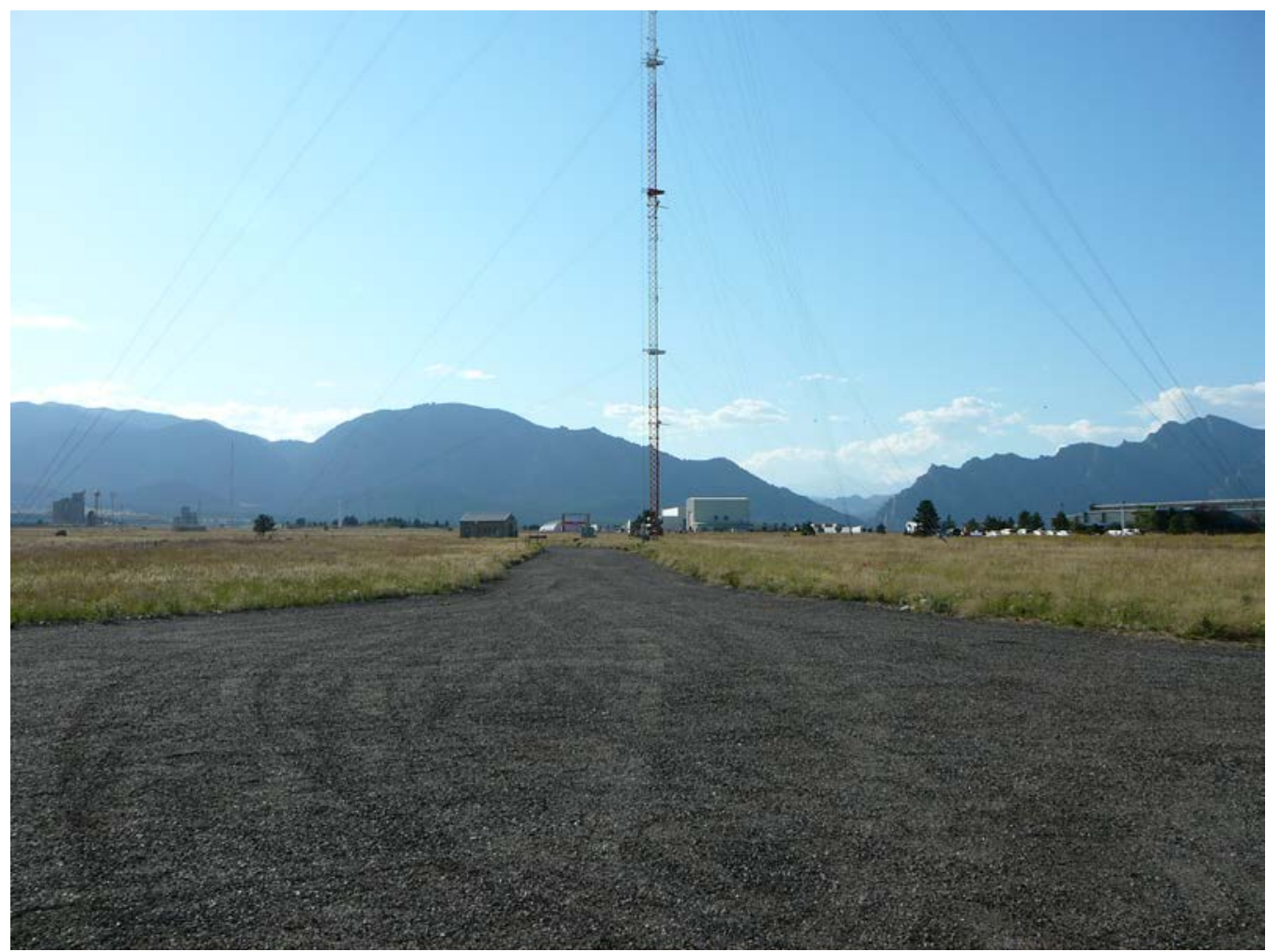

Figure A-7. At the base of the tower facing west. Photo by Ismael Mendoza, NREL

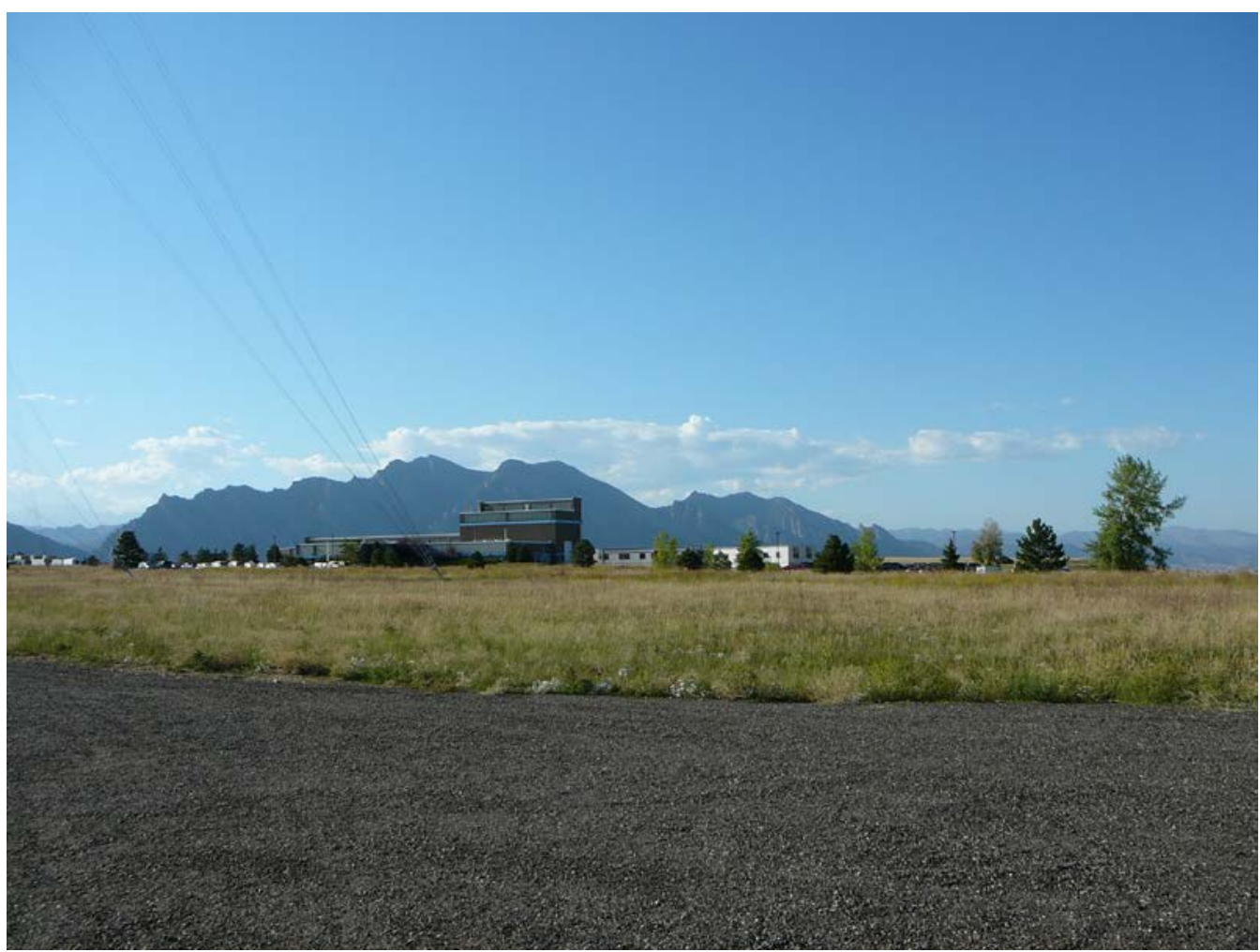

Figure A-8. At the base of the tower facing northwest. Photo by Ismael Mendoza, NREL 


\section{Appendix B. Equipment Calibration Sheets}

\section{Power}

\section{Calibration Report}

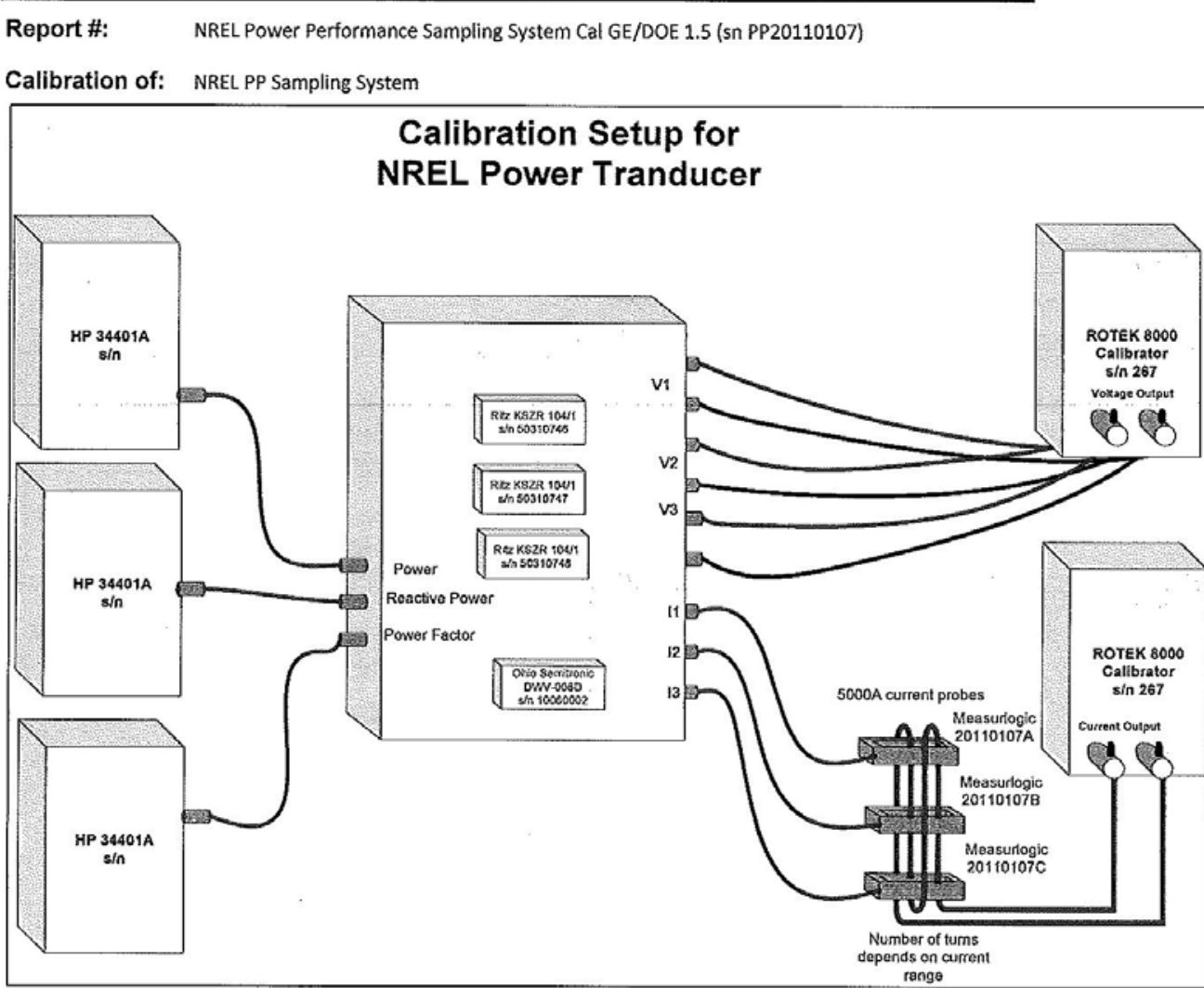

Calibration Method: Calibration Results:

Device Condition:

Date Calibrated:

Calibration Due Date:

Calibrated by:

NREL Metrology Laboratory:

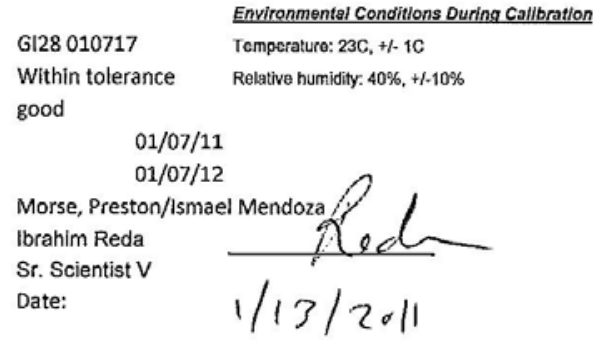

Page 1 of 4

Figure B-1. Calibration sheet for the power transducer (page 1) 
Calibration Standard:

\begin{tabular}{|c|c|c|}
\hline Model: & DOE\# & Callbration Due Date: \\
\hline 8000A & 126314 & $7 / 8 / 2011$ \\
\hline $34401 \mathrm{~A}$ & $01886 \mathrm{C}$ & $1 / 1212012$ \\
\hline $34401 \mathrm{~A}$ & $01888 \mathrm{C}$ & $3 / 5 / 2011$ \\
\hline $34401 \mathrm{~A}$ & $02301 \mathrm{C}$ & $3 / 5 / 2011$ \\
\hline
\end{tabular}

\begin{tabular}{|c|c|c|c|c|}
\hline & Current $(<50 \mathrm{~A})$ : & $0.038 \%$ of selting & 0,005 & $\%$ of rango \\
\hline & Current (>50A): & $0.05 \%$ of reading & 0.008 & $\%$ of rango \\
\hline & Voltage (Meter) & $0.0035 \%$ of reading & 0.0005 & $\%$ of range \\
\hline & Voltage(Calibrator): $(0.03+0.004)$ & $\%$ of reading & 0.01 & $\mathrm{v}$ \\
\hline & & & & Full Range \\
\hline Full Scale Settings & & \multicolumn{2}{|c|}{ Power Uncertainty, U95 (KW) } & 0.38 \\
\hline Rotek 8000 A Current: & $200 \mathrm{~A}$ & & \\
\hline Rotek 8000 A Voltage: & $700 \mathrm{~V}$ & & & \\
\hline
\end{tabular}

Unit Under Test (UUT):

\begin{tabular}{|c|c|c|c|c|c|c|c|}
\hline \multicolumn{8}{|c|}{ Current sonsors } \\
\hline Model: & Measuriogic MLG-TP816 & & & Output: & -5 & to & v \\
\hline Accuracy: & \multicolumn{3}{|c|}{$0.5 \%$ of F.S. } & Nominal Slope: & \multicolumn{3}{|c|}{1000} \\
\hline Full scale: & & -5000 & $5000 \mathrm{~A}$ & Nominal Offset: & \multicolumn{3}{|c|}{0} \\
\hline \multicolumn{8}{|c|}{ Voltege sensors } \\
\hline Model: & Ríz KSZR 104/1 & & & Output: & -100 & 100 & $0 \mathrm{~V}$ \\
\hline Accuracy: & \multicolumn{3}{|c|}{$0.5 \%$ of F.S. } & Nominal Slope: & \multicolumn{3}{|c|}{10.00} \\
\hline Full scale: & & -1000 & $1000 \mathrm{~V}$ & Nominal Offset: & \multicolumn{3}{|c|}{0} \\
\hline \multicolumn{8}{|c|}{ Power Transducer } \\
\hline Modol: & OSI DWV-008D & & & Output: & -10 & 10 & V \\
\hline \multirow[t]{2}{*}{ Accuracy: } & \multicolumn{3}{|c|}{$0.5 \%$ of F.S. } & Nominal Slope: & \multicolumn{3}{|c|}{300.00} \\
\hline & & -3000 & $3000 \mathrm{~kW}$ & & & & \\
\hline Full scale: & & 3000 & 3000 KVAR & Nominal Offset: & & 0 & \\
\hline
\end{tabular}

Uncertainty of UUT:

TUR

Note:

1. The Test Uncertainty Ratio (TUR) - The uncertainty of the unit under test (UUT) fivided by the uncertainty of the standard.

2. All uncertainties are caiculated using the Volt or Amper values, not percentages.

3. The total uncertainty for the UUT is calculated as the RSS of the uncertainties of the current and voltage sensors, and AVD converter

\begin{tabular}{|c|c|c|c|}
\hline \multicolumn{3}{|c|}{ Apparent Power } & Rotek 8000 Settings \\
\hline Watts(kW) & Voltage Output (V) & Error & Voltage: 333.33 \\
\hline 2000 & 6.699 & 0.25 & Power factor: 1 \\
\hline 1400 & 4.689 & 0.00 & \\
\hline 800 & 2.679 & -0.24 \\
\hline 200 & 0.669 & -0.49 \\
\hline 0 & 0.000197 & -0.21 \\
\hline-200 & -0.666 & 0.84 \\
\hline-800 & -2.678 & 0.00 \\
\hline-1400 & -4.689 & -0.55 \\
\hline-2000 & -6.695 & 0.40 \\
\hline
\end{tabular}

\begin{tabular}{|l|r|}
\hline Slope & 298.6295964 \\
\hline Offset & -0.2719852 \\
\hline
\end{tabular}

Page 2 of 4

Figure B-2. Calibration sheet for the power transducer (page 2) 
Reactive Power $=$ SQRT $\left[(\text { Apparent Power })^{2}-(\text { Apparent Power * PF })^{2}\right]$

\begin{tabular}{|c|c|c|c|c|}
\hline \multicolumn{4}{|c|}{ Reactive Power } & Rotek 8000 Settings \\
\hline Power Factor & Reactive power (VAR) & Voltage Output (V) & Error & Voltage: 333.33 \\
\hline 1 & 0.000 & 0.0154 & -0.91 & Apparent Power: $2000 \mathrm{~kW}$ \\
\hline 0.9 & 871.780 & 2.93 & -0.59 & \\
\hline 0.8 & 1200.000 & 4.026 & -0.87 \\
\hline 0.7 & 1428.286 & 4.812 & 6.03 \\
\hline 0.6 & 1600.000 & 5.37 & 1.27 \\
\hline 0.5 & 1732.051 & 5.802 & -1.52 \\
\hline 0.4 & 1833.030 & 6.138 & -1.96 \\
\hline 0.3 & 1907.878 & 6.394 & -0.21 \\
\hline 0.2 & 1959.592 & 6.572 & 1.34 \\
\hline 0.1 & 1989.975 & 6.665 & -1.22 \\
\hline 0 & 2000.000 & 6.698 & -1.37 \\
\hline
\end{tabular}

\begin{tabular}{|l|r|}
\hline Slope & 299.2167532 \\
\hline Offset & -5.519904617 \\
\hline
\end{tabular}

\begin{tabular}{|c|c|c|c|}
\hline \multicolumn{3}{|c|}{ Power Factor (PF) } & Rotek 8000 Settings \\
\hline Power Factor & Voltage Output (V) & Error & Voltage: 333.33 \\
\hline 1 & 10.007 & 0.00 & Apparent Power: $2000 \mathrm{~kW}$ \\
\hline 0.9 & 8.987 & 0.00 & \\
\hline 0.8 & 8.004 & 0.00 \\
\hline 0.7 & 6.993 & 0.00 \\
\hline 0.6 & 5.999 & 0.00 \\
\hline 0.5 & 4.99 & 0.00 \\
\hline 0.4 & 3.985 & 0.00 \\
\hline 0.3 & 2.982 & 0.00 \\
\hline 0.2 & 1.993 & 0.00 \\
\hline 0.1 & 0.983 & 0.00 \\
\hline 0 & 0.02333 & 0.00 \\
\hline
\end{tabular}

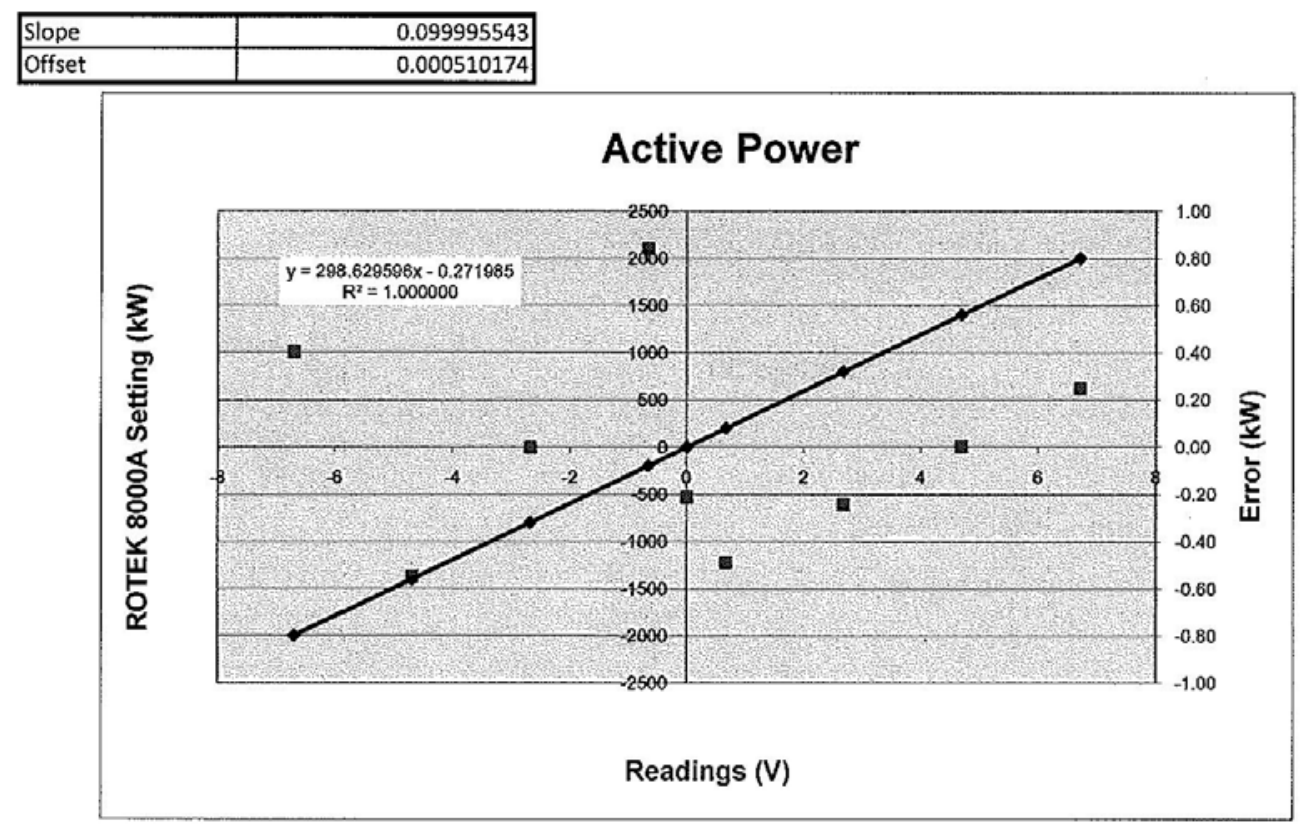

Page 3 of 4

Figure B-3. Calibration sheet for the power transducer (page 3) 

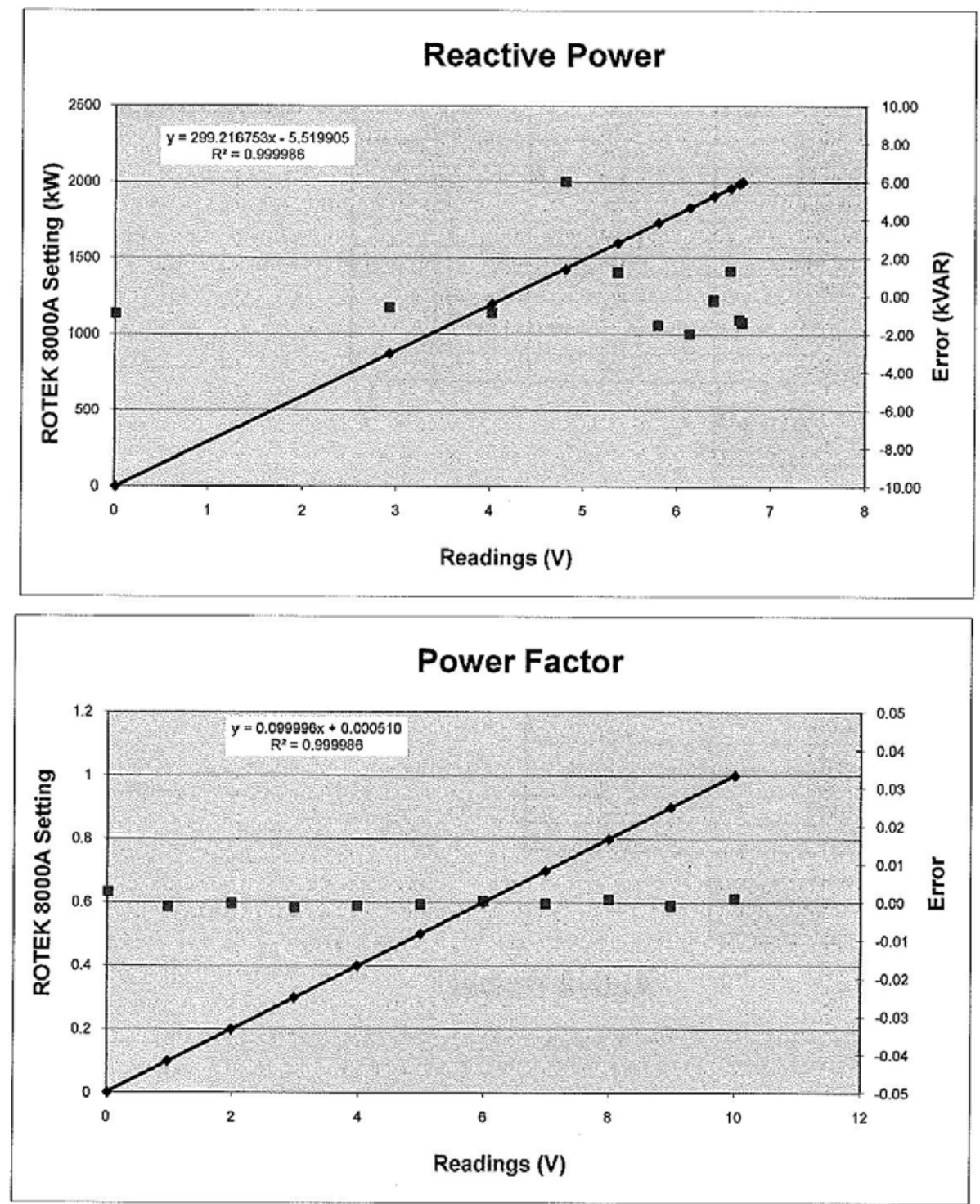

Page 4 of 4

Figure B-4. Calibration sheet for the power transducer (page 4) 


\section{Wind Speed}

\section{DEUTSCHER KALIBRIERDIENST DKD}

Kalibrierlaboratorium / Calibration laboratory

Akkreditiert durch die / accredited by the

Akkreditierungsstelle des Deutschen Kalibrierdienstes
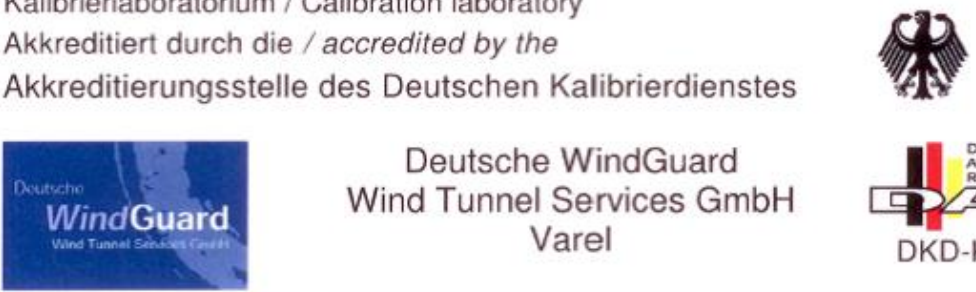
Deutsche WindGuard
Wind Tunnel Services GmbH Varel

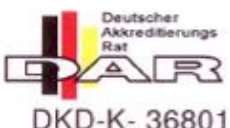

\begin{tabular}{lll}
\hline & &
\end{tabular}

Dieser Kalibrierschein darf nur vollstāndig und unverāndert weiterverbreitet werden. Auszüge oder Änderungen bedürfen der Genehmigung sowohl der Akkreditierungsstelle des DKD als auch des ausstellenden Kalibrierlaboratoriums. Kalibrierscheine ohne Unterschrift und Stempel haben keine Gültigkeit.

This calibration certificate may not be reproduced other than in full except with the permission of both the Accreditation Body of the DKD and the issuing laboratory. Calibration certificates without signature and seal are not valid.

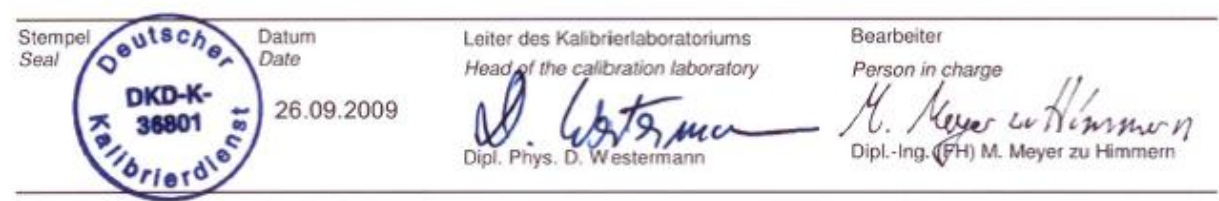

Deutsche WindGuard Wind Tunnel Services GmbH Oldenburger Str. 65

26316 Varel ; Tel. $++49(0) 445195150$

Figure B-5. Calibration sheet for the primary anemometer (page 1) 


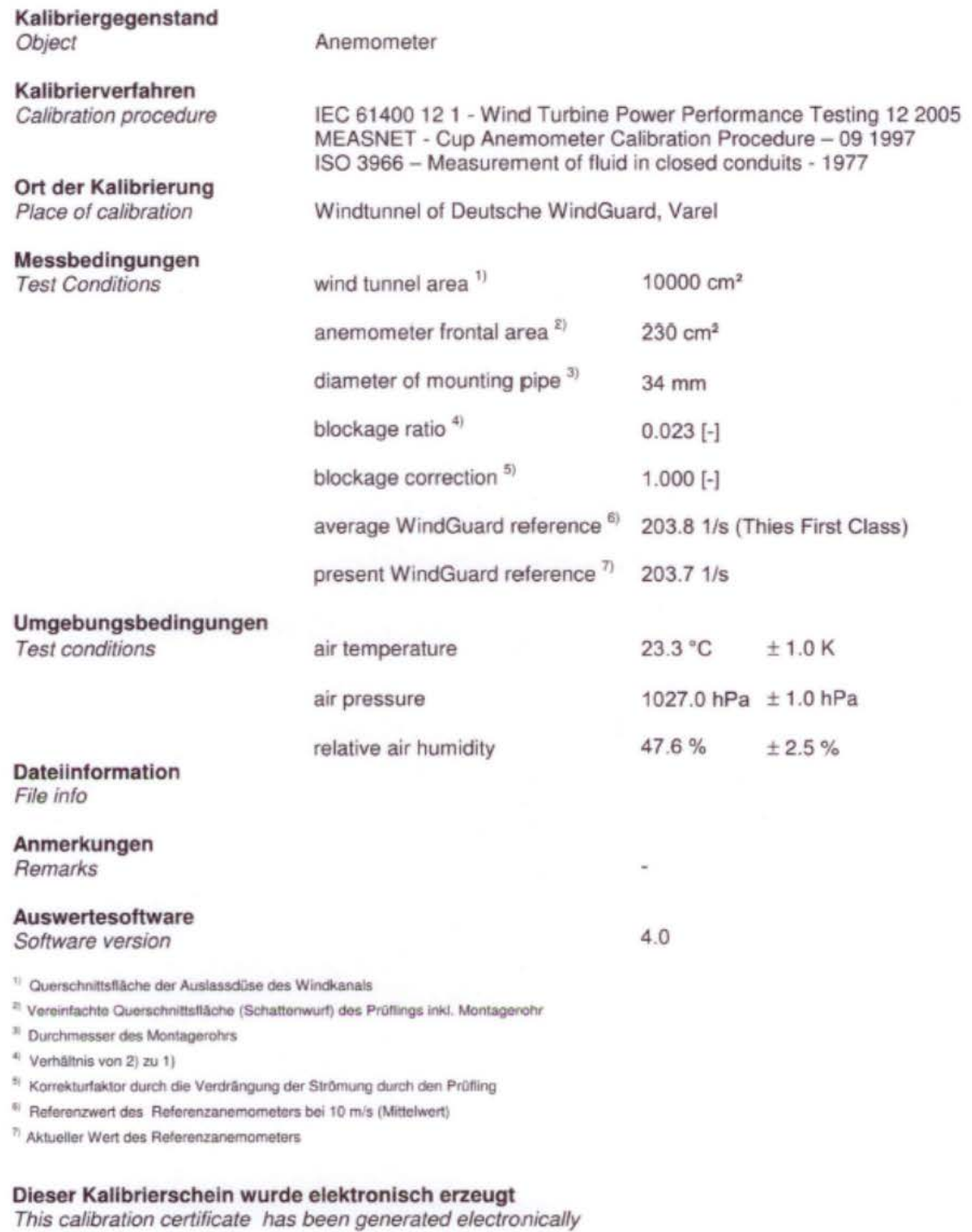

Figure B-6. Calibration sheet for the primary anemometer (page 2) 
Kalibrierergebnis:

Resuit:

\begin{tabular}{|c|c|c|}
\hline Test Item $(1 / \mathrm{s})$ & Tunnel Speed $(\mathrm{m} / \mathrm{s})$ & Uncertainty $(\mathrm{k}=2)(\mathrm{m} / \mathrm{s})$ \\
\hline 86.363 & 4.193 & 0.10 \\
\hline 129.019 & 6.143 & 0.10 \\
\hline 170.212 & 8.052 & 0.10 \\
\hline 210.679 & 9.898 & 0.10 \\
\hline 253.862 & 11.878 & 0.10 \\
\hline 297.703 & 13.858 & 0.10 \\
\hline 339.982 & 15.828 & 0.11 \\
\hline 317.337 & 14.775 & 0.10 \\
\hline 276.809 & 12.867 & 0.10 \\
\hline 232.163 & 10.870 & 0.10 \\
\hline 190.126 & 8.932 & 0.10 \\
\hline 148.153 & 7.021 & 0.10 \\
\hline 108.825 & 5.222 & 0.10 \\
\hline & & \\
\hline
\end{tabular}

Angegeben ist die enweiterte Messunsicherheit, die sich aus der Standardmessunsicherheit durch Multiplikation mit dem Enweiterungsfaktor $k=2$ ergibt. Sie wurde gemäß DKD-3 ermittelt. Der Wert der Messgröße liegt mit einer Wahrscheinlichkeit von $95 \%$ im zugeordneten Wertintervall.

Der Deutsche Kalibrierdienst ist Unterzeichner der multilateralen Ubereinkommen der European cooperation for Accreditation (EA) und der International Laboratory Accreditation Cooperation (ILAC) zur gegenseitigen Anerkennung der Kalibrierscheine. Die weiteren Unterzeichner innerhalb und außerhalb Europas sind den Internetseiten von EA (www.european-accreditation.org) und ILAC (www.ilac.org) zu entnehmen.

The expanded uncertainty assigned to the mea-surement results is obtained by multiplying the standard uncertainty by the coverage factor $k=2$. It has been determined in accordance with DKD-3. The value of the measurand lies within the assigned range of values with a probability of $95 \%$.

The DKD is signatory to the multilateral agree-ments of the European co-operation for Accredita-tion (EA) and of the International Laboratory Accreditation Cooperation (ILAC) for the mutual recognition of calibration certificates.

Figure B-7. Calibration sheet for the primary anemometer (page 3) 


\section{Detailed MEASNET ${ }^{1}$ Calibration Results}

$\begin{array}{ll}\text { DKD calibration no. } & 09 / 5843 \\ \text { Body no. } & 0909219 \\ \text { Cup no. } & 0909219 \\ \text { Date } & 26.09 .2009 \\ \text { Air temperature } & 23.3^{\circ} \mathrm{C} \\ \text { Air pressure } & 1027.0 \mathrm{hPa} \\ \text { Humidity } & 47.6 \%\end{array}$

Linear regression analysis

Slope

Ollsel

St.err(Y)

Correlation coefficient

Remarks

$0.017 \mathrm{~m} / \mathrm{s}$

0.999989

no

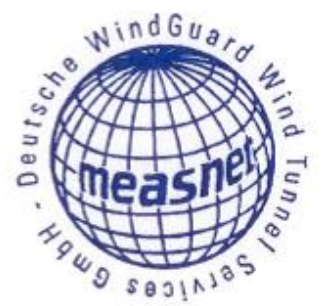

$0.04579(\mathrm{~m} / \mathrm{s}) /(1 / \mathrm{s}) \pm 0.00006(\mathrm{~m} / \mathrm{s}) /(1 / \mathrm{s})$

$0.239 \mathrm{~m} / \mathrm{s} \pm 0.015 \mathrm{~m} / \mathrm{s}$

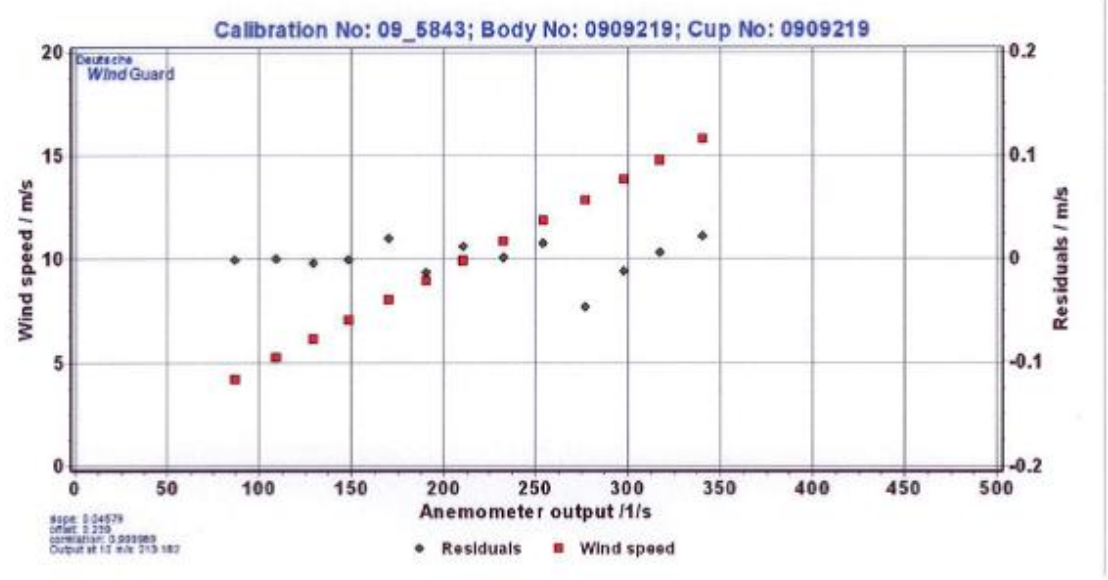

1) According to MEASNET Cup Anemometer Calibration Procedure 09/1997.

Deutsche WindGuard Wind Tunnel Services is accredited by MEASNET and by the Deutscher Kalibrierdienst

- DKD ( German Calibration Service). Registration: DKD - K - 36801

Deutsche WindGuard Wind Tunnel Services GmbH

Oldenburger Str. 65

26316 Varel ; Tel. ++49 (0) 445195150

Figure B-8. Calibration sheet for the primary anemometer (page 4) 

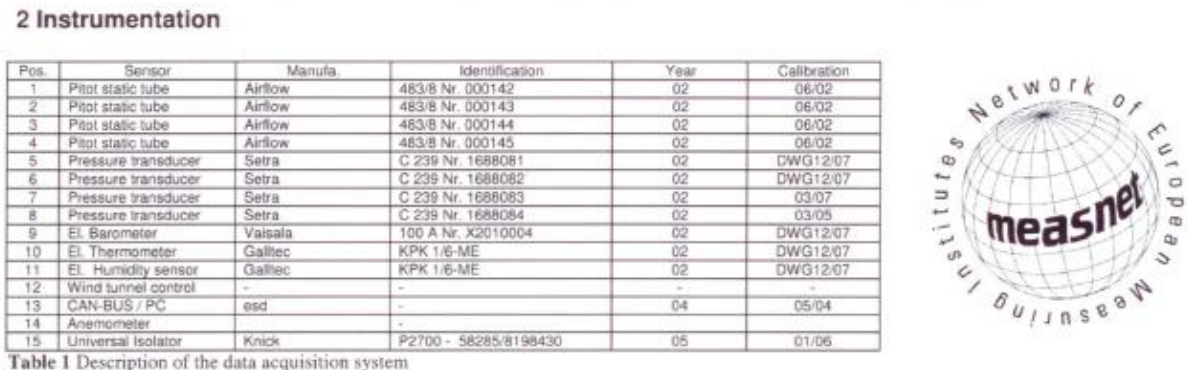

3 Photo of the calibration set-up
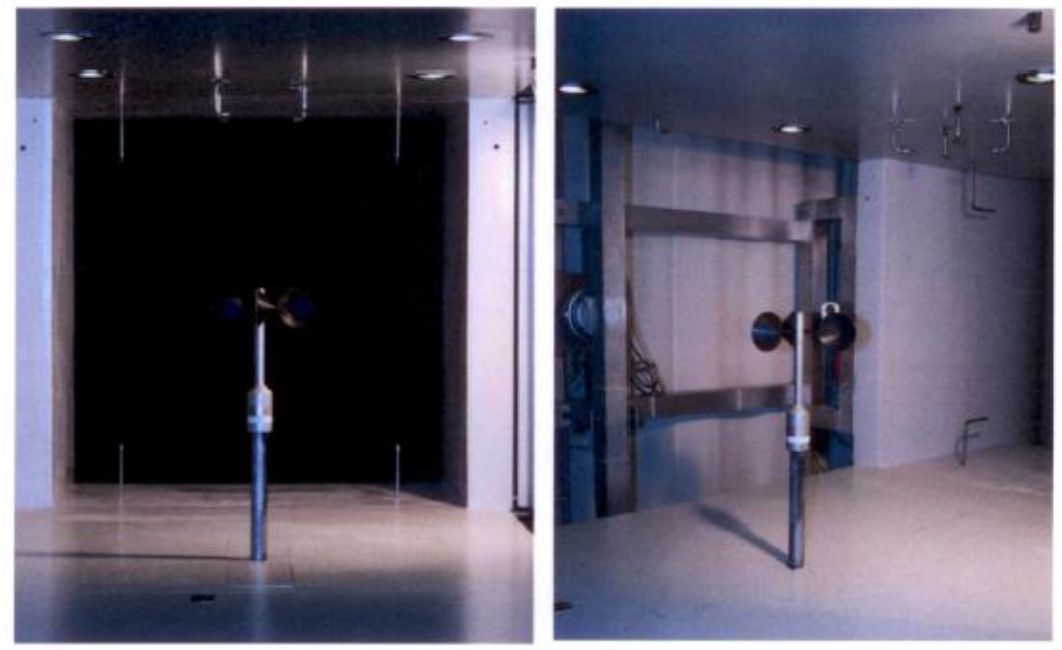

Calibration set-up of the anemometer calibration in the wind tunnel of Deutsche WindGuard, Vare!.

The annemometer shown is of the same type as the calibrated one. Remark: The proportion of the set-up are not true to scale due to imaging geometry.

4 Deviation to MEASNET procedure

The calibration procedure is in all aspects in accordance with the IEC 61400-12-1 Procedure

5 References

[1] J. Mander, D. Westermann, 12/2007 - Verfahrensanweisung DKD-Kalibrierung von Windgeschwindigkeitssensoren

[2] IEC 61400-12-1 12/2005 - Wind Turbine Power Performance Testing

[3] ISO 39661977 - Measurement of fluid flow in closed conduits

[4] MEASNET 091997 - Cup Anemometer Calibration Procedure

Deutsche WindGuard Wind Tunnel Services GmbH

Oldenburger Str. 65

26316 Varel : Tel. ++49 (0)445195150

\section{WindGuard}

Figure B-9. Calibration sheet for the primary anemometer (page 5) 


\section{Test Certificate}

Model: SS201

Sensor Serial No: K16684

Job Number:

Customer:

Test Date: $\quad 12 / 10 / 2010$

Tested by: D. Hoagland

Room Temperature: $\quad 24.6 \quad{ }^{\circ} \mathrm{C}$

Room Relative Humidity:

42.9

$\%$

Recommended calibration interval is 12 months from the first day of use.

\section{Calibration Standards}

\begin{tabular}{|l|c|c|c|c|}
\hline \multicolumn{1}{|c|}{ Standards } & Manufacturer & Model & SN & Cal Due \\
\hline DMM & HEWLETT PACKARD & $3468 \mathrm{~B}$ & 2231 A01057 & April 7, 2011 \\
\hline TEMPERATURE & ROSEMONT & T-200 & 1171688 & January 12, 2011 \\
\hline RH Sensor & Met One Instruments & $083 \mathrm{D}-1-35$ & W3673 & June 26, 2011 \\
\hline BAROMETRIC PRESSURE & MET ONE INSTRUMENTS & $090 \mathrm{~B}$ & H6507 & July 2, 2011 \\
\hline & & & & \\
\hline
\end{tabular}

\section{Test Data}

\begin{tabular}{|c|c|c|c|}
\hline TEST & UUT & SPEC & NOTES \\
\hline \hline OUTPUT Vpp & $10.6 \mathrm{Vpp}$ & $8.0 \mathrm{Vpp}$ Min & \\
\hline SYMMETRY \%Duty & $55.90 \%$ & $50 \pm 10 \%$ & \\
\hline CURRENT DRAIN & $3.5 \mathrm{~mA}$ & $5.0 \mathrm{~mA}$ TYP & \\
\hline STARTING TORQUE & $0.324 \mathrm{GM}-\mathrm{CM}$ & $1.0 \mathrm{GM}-\mathrm{CM} \mathrm{MAX}$ & \\
\hline SHAFT END PLAY & 0.0145 in & 0.006 to $0.020 \mathrm{in}$ & \\
\hline SHAFT \& HUB RUNOUT & 0.0005 in & 0.000 to $0.005 \mathrm{in}$ & \\
\hline & & & \\
\hline
\end{tabular}

Test Procedure \# 42061-6101, 53645-6101

The standards used for this calibration have accuracies equal to or greater than the instruments tested. These standards are on record and traceable to NIST to the extent allowed by the institute's calibration facility. Unless otherwise stated hereon, all instruments are calibrated to meet the manufacturer's published specifications. The Calibration system complies with MIL-STD-45662A.

SS201-9600 Rev B

Figure B-10. Calibration sheet for the reference anemometer (page 1) 


\section{Wind Direction}

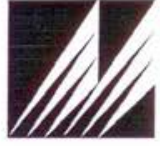

Met One Instruments, Inc.

1600 NW Washington Blvd.

Grants Pass, Oregon 97526

Telephone 541-471-7111

Facsimile 541-541-7116

Regional Service

3206 Main St. Suite 106

Rowlett, Texas 75088

Telephone 972-412-4715

Facsimile 972-412-4716

\section{Test Certificate}

Model: SD201

Sensor Serial No: K16689

Job Number:

Customer:

Tested by:

D. Hoagland

Room Relative Humidity:

42.9

$\%$

Recommended calibration interval is 12 months from the first day of use.

\section{Calibration Standards}

\begin{tabular}{|c|c|c|c|c|}
\hline Standards & Manufacturer & Moded & SHA & Cal Due \\
\hline DMM & HEWLETT PACKQ RD & $3458 \mathrm{~B}$ & 22310001057 & April 7.2011 \\
\hline TEMPERRTURE & ROSEMONT & T.200 & 1171688 & January 12,2011 \\
\hline RH Sersor & Met One Instrumerts & $0830-1.35$ & W3673 & June 26,2011 \\
\hline BAROM ETRIC PRESSURE & MET ONE INSTRUMENTS & $090 \mathrm{~B}$ & H6507 & July 2,2011 \\
\hline
\end{tabular}

Test Data

\begin{tabular}{|c|c|c|c|c|c|}
\hline TEST & OUTPUT VOLTS & INDICATED ${ }^{\circ}$ & ERROR $^{\circ}$ & SPEC & NOTES \\
\hline $0^{\circ}$ & 0.001 & 0.1 & 0.1 & $\pm 5^{\circ}$ & \\
\hline $30^{\circ}$ & 0.299 & 29.9 & -0.1 & $\pm 5^{\circ}$ & \\
\hline $60^{\circ}$ & 0.601 & 60.1 & 0.1 & $\pm 5^{\circ}$ & \\
\hline $90^{\circ}$ & 0.905 & 90.5 & 0.5 & $\pm 5^{\circ}$ & \\
\hline $120^{\circ}$ & 1.204 & 120.4 & 0.4 & $\pm 5^{\circ}$ & \\
\hline $150^{\circ}$ & 1.503 & 150.3 & 0.3 & $\pm 5^{\circ}$ & \\
\hline $180^{\circ}$ & 1.804 & 180.4 & 0.4 & $\pm 5^{\circ}$ & \\
\hline $210^{\circ}$ & 2.109 & 210.9 & 0.9 & $\pm 5^{\circ}$ & \\
\hline $240^{\circ}$ & 2.416 & 241.6 & 1.6 & $\pm 5^{\circ}$ & \\
\hline $270^{\circ}$ & 2.723 & 272.3 & 2.3 & $\pm 5^{\circ}$ & \\
\hline $300^{\circ}$ & 3.030 & 303.0 & 3.0 & $\pm 5^{\circ}$ & \\
\hline $330^{\circ}$ & 3.337 & 333.7 & 3.7 & $\pm 5^{\circ}$ & \\
\hline
\end{tabular}

\begin{tabular}{|c|c|}
\hline END PLAY & 0.005 \\
\hline TORQUE & 0.040 \\
\hline
\end{tabular}

\begin{tabular}{|c|l|}
\hline NOISE CW & N/A \\
\hline NOISE CCW & N/A \\
\hline
\end{tabular}

Test Procedure \#42062-6200

The standards used for this calibration have accuracies equal to or greater than the instruments tested. These standards are on record and traceable to NIST to the extent allowed by the institute's calibration facility. Unless otherwise stated hereon, all instruments are calibrated to meet the manufacturer's published specifications. The Calibration system complies with MIL-STD-45662A.

SD210-9600 Rev B

\section{Figure B-11. Calibration sheet for the wind vane}




\section{Temperature}

Branch \#: 5000

sheet: 1 of: 1

NREL METROLOGY LABORATORY

Test Report

Test Instrument: RTD

DOE \# : $03507 C$

ModeI \# : 78NOINOONO4

$S / N \quad: 0673552$

Calibration Date: 09/23/2010

Due Date: $09 / 23 / 2011$

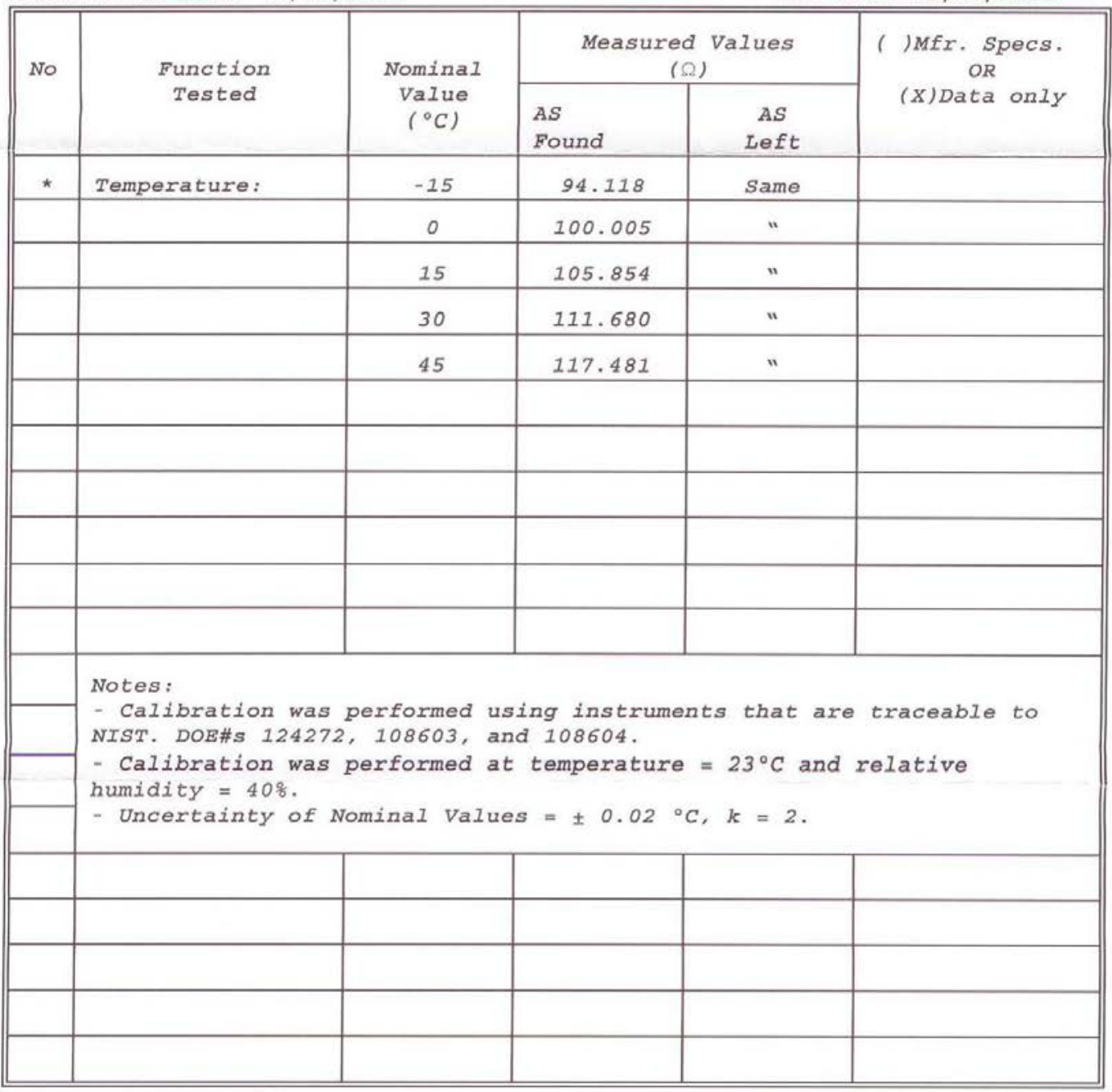

Calibrated BY: P. Morse

Approved By: D. Myers

Date: $9 / 23 / 2010$

Date: $9 / 23 / 2010$

Figure B-12. Calibration sheet for the temperature sensor 


\section{Pressure}

\section{NREL METROLOGY LABORATORY}

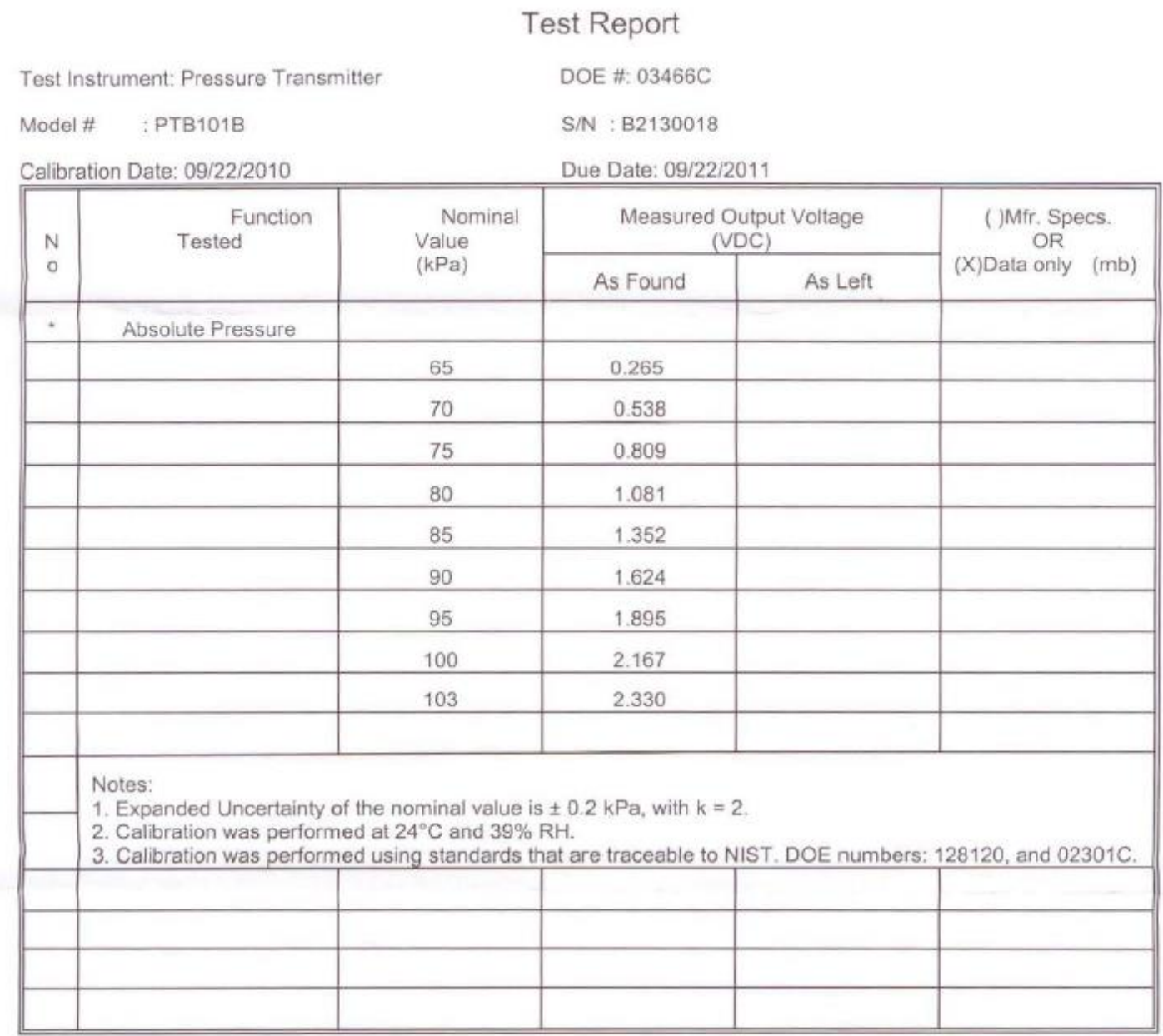

Calibrated By: P. Morse

Approved By: D. Myers Date: 09/22/2010

Figure B-13. Calibration sheet for the pressure sensor 


\section{Data Acquisition}

Certificate of Conformance

\begin{tabular}{llll} 
& & Date: & 22-FEB-2012 \\
\hline Serial Number: & 1286DD2 & 192580D-02 \\
Description: & CCA,NI 9229,PRECISION +/-60V & Part Number: & \\
& ISOLATON AMPLIFR WITH \\
ANTI-ALIAS FILTER & & \\
\hline Manufacture Date: & & & \\
\hline
\end{tabular}

National Instruments (NI) hereby certifies that the NI part numbers and quantity of this shipment are in accord with the Customer's Purchase Order. NI further certifies that the product(s) is/are new material; that the product(s) has/have been inspected and tested and conform(s) to quality and performance standards as documented in the National Instruments Quality Management System (QMS), in conformance with the ISO 9001:2000 standard.

National Instruments further certfies that the environment in which the products were tested is maintained within the operating specifications of the instrument and the standards. If any product requires calbration, the instruments used to perform the calibration are traceable to the National Institute of Standards and Technology (NIST) and/or other National Measurements Institutes (NMI's) that are signatories of the International Committee of Weights and Measures (CIPM) Mutual Recognition Arrangement (MRA).

For questions or comments, please contact National Instruments Technical Support.

$$
\text { a.kor }
$$

Andrew Krupp

Vice President, Quality and Continuous Improvement

Natonal Instruments Corporation
11500 N. Mopac Exprossway
Austin, TX 78759-3504
USA
Tel: $512-683-0100$

Figure B-14. Certificate of conformance sheet for NI 9229 signal module 


\section{Davis Calibration}

Company ID: 120205

NATIONAL RENEWABLE ENERGY LAB

BEV KAY/SRRL

16253 DENVER WEST PARKWAY

GOLDEN, CO 80401

\section{ACLAS5}

calibration

\section{Certificate of Calibration}

|| || || || || || || || || || || || || |||

4415557

Centificate Page 1 of 1

Instrument Identification

PO Number: CC-BEVERLY KAY

Instrument ID: $03893 \mathrm{C}$

Model Number: NI 9229

Manufacturer: NATIONAL INSTRUMENTS

Serial Number: 12B6DD2

Description: 4-CHANNEL, $\pm 60 \mathrm{~V}, 24-\mathrm{BIT}$ SIMULTANEOUS ANALOG INPUT

Accuracy: Mfr Specifications

\section{Certilicate Information}

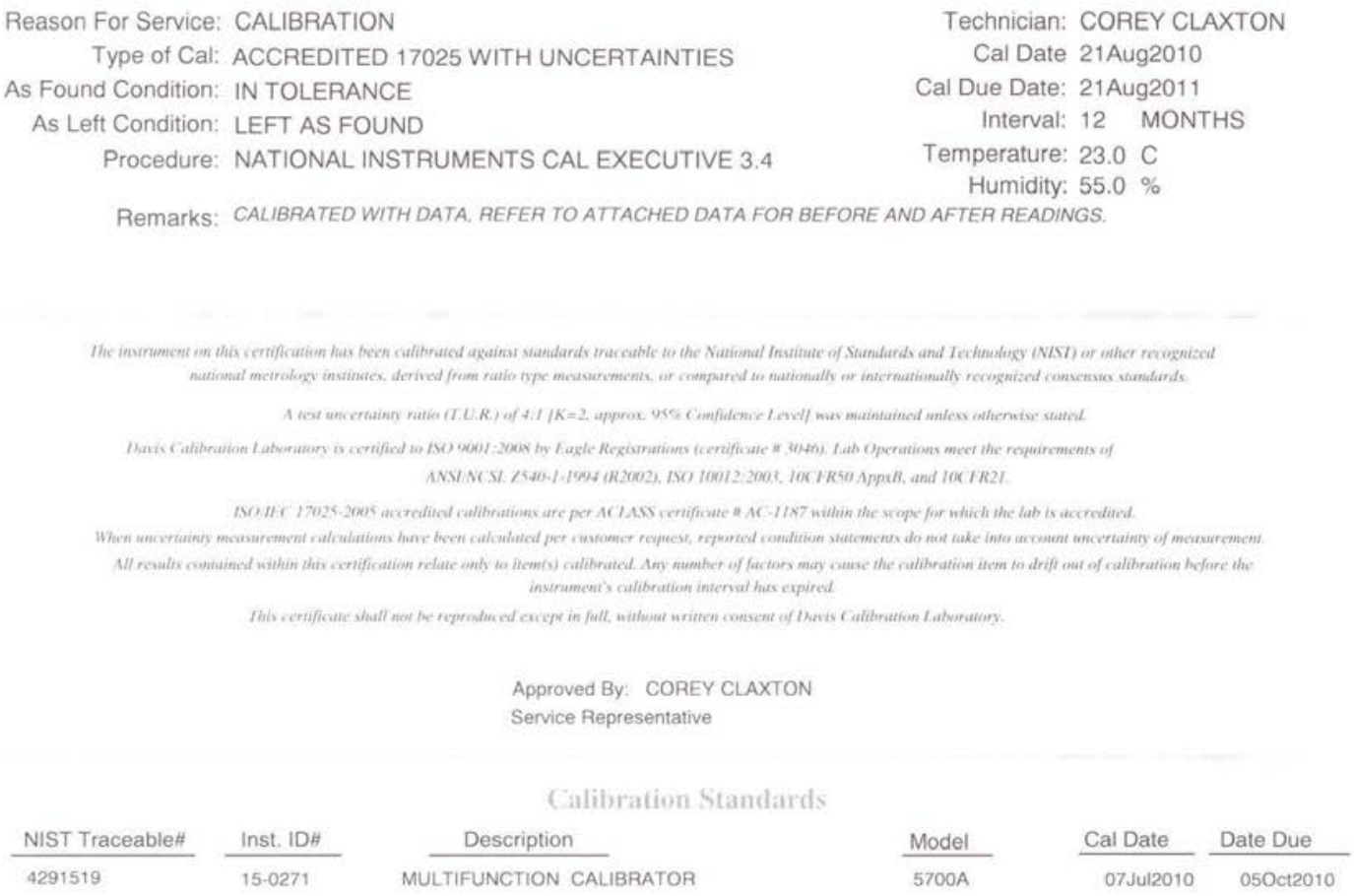

Figure B-15. Calibration sheet for NI 9229 signal module 12B6DD2 


\begin{tabular}{llll} 
Certificate of Conformance & & \\
& & Date: & 22-FEB-2012 \\
\hline $\begin{array}{l}\text { Serial Number: } \\
\text { Description: }\end{array}$ & $\begin{array}{l}\text { 12BD192 } \\
\text { CCANN 9217.4-CHANNEL CRIO } \\
\text { MODULE FOR RTD INPUTS }\end{array}$ & Part Number: & \\
\hline Manufacture Date: & & & \\
\hline
\end{tabular}

National Instruments (NI) hereby certifies that the NI part numbers and quantity of this shipment are in accord with the Customer's Purchase Order. NI further cortifies that the product(s) is/are new material; that the product(s) has/have been inspoctod and tested and conform(s) to quality and performance standards as documented in the National Instruments Quality Management System (QMS), in conformance with the ISO 9001:2000 standard.

National Instruments further certifies that the environment in which the products were tested is maintained within the operating specifications of the instrument and the standards. If any product requires calibration, the instruments used to perform the calibration are traceable to the National Institute of Standards and Technology (NIST) and/or other National Measurements Institules (NMI's) that are signatories of the International Committee of Weights and Measures (CIPM)

For questions or comments, please contact National Instruments Technical Support.

$$
\text { arkmors }
$$

Andrew Krupp

Vice President, Quality and Continuous Improvement

National Instruments Corporation
11500 N. Mopac Expressway
Austin, TX 73759-3504
USA

USA : $512-683-0100$

Figure B-16. Certificate of conformance sheet for NI 9217 signal module 12BD192 


\section{Davis Calibration}

Company ID: 120205

NATIONAL RENEWABLE ENERGY LAB

BEV KAY/SRRL

16253 DENVER WEST PARKWAY

GOLDEN, CO 80401

Instrument ID: $03889 \mathrm{C}$

Manufacturer: NATIONAL INSTRUMENTS

Description: 4-CH 100 OHM 24-BIT RTD ANALOG INPUT

Accuracy: Mfr. Specifications

\section{Certificate of Calibration}

|||||||||||||||||||||||||||||||

4415599

Cenificate Page 1 of 1

Imstrument Identification

PO Number: CC-BEVERLY KAY

Model Number: NI 9217

Serial Number: 12BD192

Certilicate Information

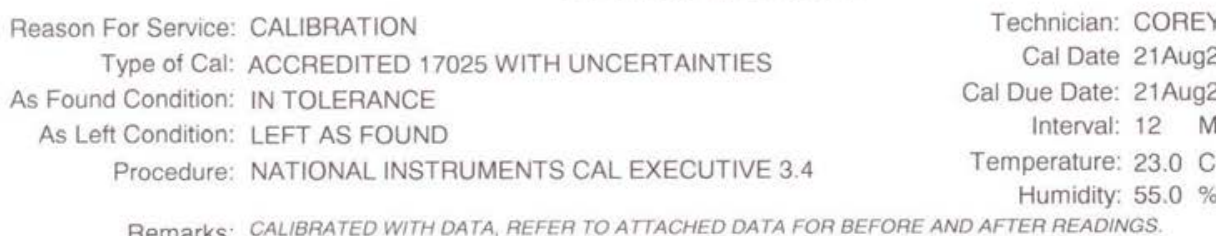

Figure B-17. Calibration sheet for NI 9217 signal module 12BD192 


\section{Certificate of Conformance}

\begin{tabular}{llll} 
& & Date: & 22-FEB-2012 \\
\hline Serial Number: & 12E9CD3 & Part Number: & 193299F-01 \\
Description: & CCA,9205,16 BIT 32 CH VOLTAGE & & \\
& ANALOG INPUT MODULE (MIO & & \\
& CLASS) & \\
\hline Manufacture Date: & & \\
\hline
\end{tabular}

National Instruments (NI) hereby certifies that the NI part numbers and quantity of this shipment are in accord with the Customer's Purchase Order. NI further certifies that the product(s) is/are new material; that the product(s) has/have been inspected and tested and conform(s) to quality and performance standards as documented in the National Instruments Quality Management System (QMS), in conformance with the ISO 9001:2000 standard.

National Instruments further certifies that the environment in which the products were tested is maintained within the operating specifications of the instrument and the standards. If any product requires calibration, the instruments used to perform the calibration are traceable to the National Institute of Standards and Technology (NIST) and/or other National Measurements Institutes (NMI's) that are signatories of the International Committee of Weights and Measures (CIPM) Mutual Recognition Arrangement (MRA).

For questions or comments, please contact National Instruments Technical Support

\section{arkm}

Andrew Krupp

Vice President, Quality and Continuous Improvement

National Instruments Corporation
11500 N. Mopac Expressway
Austin, TX 78759-3504
USA
Tel: $512-683-0100$

Tel: 512-683-0100

Figure B-18. Certificate of conformance sheet for NI 9205 signal module 12E9CD3 
Davis Calibration

Company ID: 120205

NATIONAL RENEWABLE ENERGY LAB

BEV KAY/SRRL

16253 DENVER WEST PARKWAY

GOLDEN, CO 80401
ACLASS Certificate of Calibration | |||||||||||||||||||||||||||||||||

4415656

Certificate Page 1 of 1

Instrument Identification

PO Number: CC-BEVERLY KAY

Instrument ID: 03886C Model Number: NI 9205

Manufacturer: NATIONAL INSTRUMENTS Serial Number: 12E9CD3

Description: $32-\mathrm{CH} \pm 200 \mathrm{MV}$ TO $\pm 10 \mathrm{~V}, 16-\mathrm{BIT}, 250 \mathrm{KS} / \mathrm{S}$ ANALOG INPUT MODULE

\title{
Certilicate Information
}

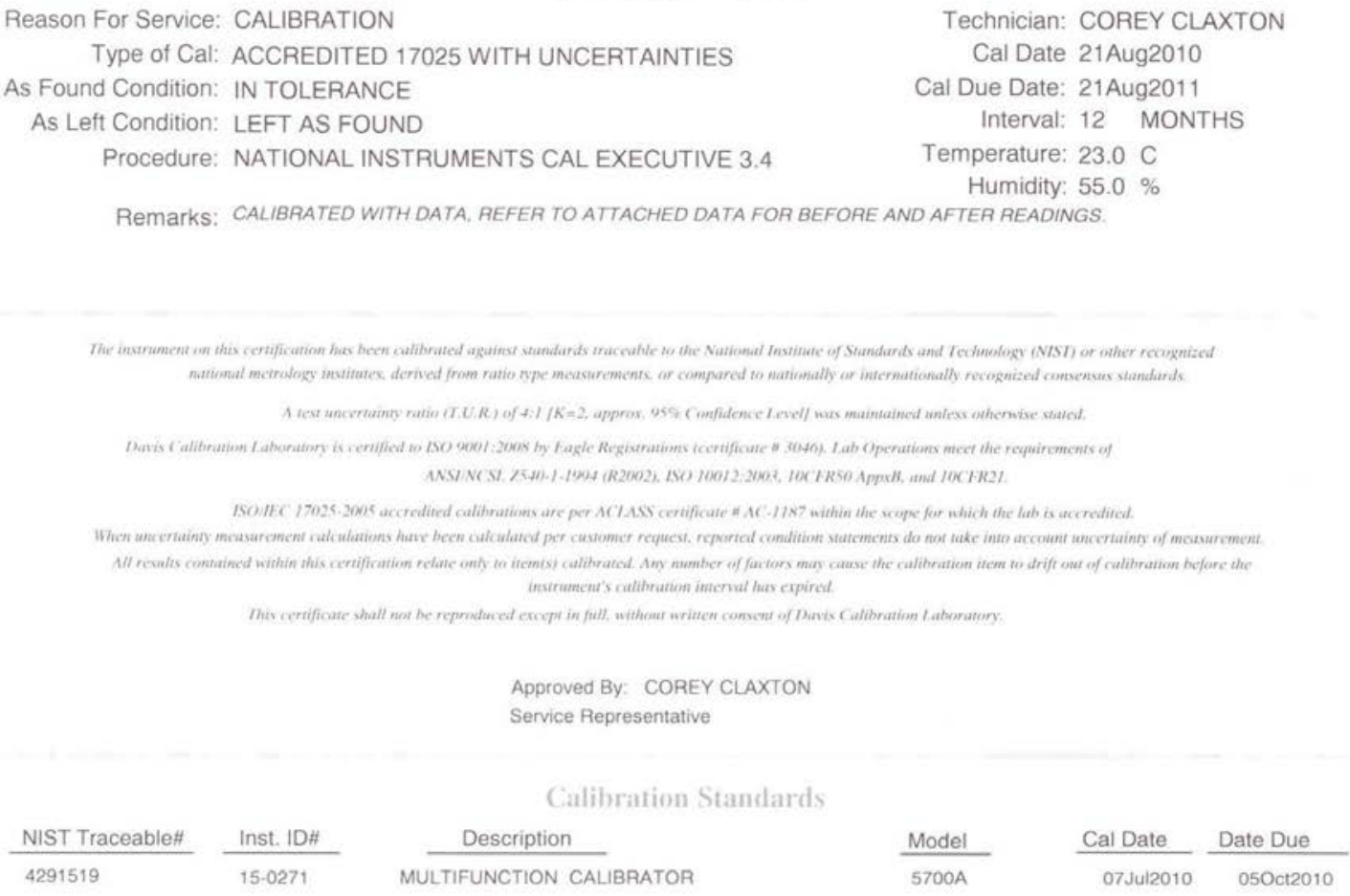

\begin{abstract}
$15-0271$
\end{abstract}

\begin{abstract}
MULTIFUNCTION CALIBRATOR
\end{abstract}
Davis Calibration · 2324 Ridgepoint Drive, Suite D - Austin, TX 78754 • Phone: 800-365-0147 • Fax: 512-926-8450

Figure B-19. Calibration sheet for NI 9205 signal module 12E9CD3 